\title{
Taxonomic Revision of Daniellia (Leguminosae: Caesalpinioideae)
}

Author(s): Manuel de la Estrella , Carlos Aedo , Barbara Mackinder , and Mauricio Velayos

Source: Systematic Botany, 35(2):296-324. 2010.

Published By: The American Society of Plant Taxonomists

URL: http://www.bioone.org/doi/full/10.1600/036364410791638414

BioOne (www.bioone.org) is a nonprofit, online aggregation of core research in the biological, ecological, and environmental sciences. BioOne provides a sustainable online platform for over 170 journals and books published by nonprofit societies, associations, museums, institutions, and presses.

Your use of this PDF, the BioOne Web site, and all posted and associated content indicates your acceptance of BioOne's Terms of Use, available at www.bioone.org/page/terms of use.

Usage of BioOne content is strictly limited to personal, educational, and non-commercial use. Commercial inquiries or rights and permissions requests should be directed to the individual publisher as copyright holder. 


\title{
Taxonomic Revision of Daniellia (Leguminosae: Caesalpinioideae)
}

\author{
Manuel de la Estrella, ${ }^{1,3,4}$ Carlos Aedo, ${ }^{1}$ Barbara Mackinder, ${ }^{2}$ and Mauricio Velayos ${ }^{1}$ \\ ${ }^{1}$ Real Jardín Botánico, CSIC, Plaza de Murillo 2, 28014 Madrid, Spain \\ ${ }^{2}$ Royal Botanic Gardens, Kew, Richmond, Surrey, TW9 3AB United Kingdom \\ ${ }^{3}$ Departamento de Botánica, Ecología y Fisiología Vegetal, Universidad de Córdoba, \\ Facultad de Ciencias, Campus de Rabanales, Edificio José Celestino Mutis, 14071 Córdoba, Spain \\ ${ }^{4}$ Author for correspondence (mdelaestrella@gmail.com)
}

\section{Communicating Editor: Andrea Schwarzbach}

\begin{abstract}
Daniellia (Leguminosae: Caesalpinioideae) is a genus of ten species of medium to large trees from tropical and subtropical Africa. In contrast to earlier accounts, $D$. mortehanii is treated here as a synonym of $D$. pynaertii, and D. oblonga, which previously has been treated by some authors as a synonym of $D$. thurifera, is accepted. In addition, we describe as new Daniellia glandulosa. Quantitative characters such as receptacle length, petiole width, sepal length, and largest leaflet length have been used to aid species differentiation following the results of recent morphometric studies that revealed their taxonomic utility. Micromorphological features such as pollen surface and leaf glands were studied in all species, many for the first time, and the number, position, and shape of the glands present in the leaves are shown to be taxonomically useful in distinguishing species. A dichotomous key and a table of key characters is provided, as well as detailed descriptions and distribution maps for each species. All species are illustrated, D. oblonga and D. glandulosa for the first time. Three lectotypes and a neotype are designated.
\end{abstract}

Keywords-Africa, Daniellia glandulosa, rain forest, savannah, taxonomy.

Daniellia Benn. (Leguminosae: Caesalpinioideae) is a genus of ten species of medium to large trees restricted to tropical and subtropical Africa, but found in a diverse range of habitats from swampy areas to seasonally dry forest at 0-1,500 m altitude (Mackinder 2005). The highest concentration of species and morphological variation is found in the GuineoCongolian region.

Daniellia is characterized by the combination of flowers with four imbricate sepals, five petals, ten stamens (all free or nine shortly connate) and fruits that are 'hemi-legumes', i.e. those where the single seed, attached by a long funicle, is dispersed with one valve of the fruit (Aubréville 1970; Cowan and Polhill 1981; Mackinder 2005). This combination of characters differentiates Daniellia from the closely related genera Eurypetalum Harms, Augouardia Pellegr., and Stemonocoleus Harms.

Daniellia was named in 1854 for W. F. Daniell who collected the type specimen of Daniellia thurifera in Sierra Leone. Later, Oliver (1871) described Daniellia oblonga which was transferred to the new genus Cyanothyrsus by Harms (1897). Harms subsequently published two new species Cyanothyrsus soyauxii and C. ogea (Harms 1899). Based on new morphological studies, Harms (1908) placed Cyanothyrsus in synonymy under Daniellia. Rolfe (1912) described Paradaniellia oliveri which Hutchinson and Dalziel (1928a) treated as synonymous with Daniellia. In the first published key of the genus, eight species were accepted (Hutchinson and Dalziel 1928b). Species boundaries were defined by the number of lateral nerves per leaflet, the number and shape of leaflets, and the ovary indumentum, but these characters have little taxonomic utility as they are variable within species (Estrella et al. 2009).

Baker (1930) recognised 12 species in Daniellia and proposed the currently accepted subgeneric division of the genus: subgenus Eudaniellia (later corrected to subgen. Daniellia) and subgenus Paradaniellia.

Pellegrin (1949) reported eight species for the flora of Gabon including $D$. pubescens and D. similis (treated here as synonyms of $D$. pynaertii and D. ogea respectively). He introduced the use of the indumentum of the midrib of the lower surface of the leaflet as a character for differentiating species. Léonard
(1950, 1952) accepted 12 species and two varieties and used two new characters that we have found taxonomically useful in our study: pedicel length and petiolule length (Estrella et al. 2009). Keay (1954) placed five of the taxa accepted by Léonard into the synonymy of other species.

Keay (1958) recognized five species (D. oblonga, D. ogea, D. oliveri, D. pynaertii, and D. thurifera) for the second edition of the Flora of West Tropical Africa. He used length and size of the pedicel and sepal indumentum to define species; we have also found these characters to be taxonomicaly significant (Estrella et al. 2009).

Major floras of tropical Africa have presented conflicting treatments of Daniellia albeit they usually include only a few species of the genus (Aubréville 1950, 1959; Berhaut 1967; Brenan 1967; de Koning 1983; Hawthorne and Jongkind 2006; Timberlake et al. 2007).

Since the first edition of the Flora of West Tropical Africa (Hutchinson and Dalziel 1928b) all authors have treated Daniellia as a natural group. Their views are supported by recent phylogenetic works (Bruneau et al. 2001; Herendeen et al. 2003; Fougère-Danezan et al. 2007) which place a strongly supported, monophyletic Daniellia as sister to a clade comprising the other genera of Detarieae sensu stricto including Eurypetalum Harms, Eperua Aubl., and Augouardia Pellegr. (Mackinder 2005).

Using a morphometric approach to the genus (Estrella et al. 2009), we found that some morphological characters not previously studied in detail are useful in species delimitation and are included in this work. They include: petiole indumentum and width, number and position of glands on the lower surface of the leaflets, and presence or absence of glands at the insertion of each pair of leaflets.

The lack of adequate material has always been a problem faced by those wishing to study this genus and there is a need for further exploration and specimen collection (Léonard 1950, p. 94; Estrella et al. 2009). We have studied most of the available collections of Daniellia and we present a taxonomic revision of this endemic African genus. Of the 20 taxa previously recognised in Daniellia, we accept nine and describe one species as new. 


\section{MATERIALS AND MethodS}

This revision is based on 534 specimens (many of them with their duplicates) (Supplemental appendix 1 online) from the following herbaria: A, AAU, B, BM, BR, C, COI, E, G, GH, H, HBG, K, L, LISC, M, MA, MO, NY, P, U, UPS, US, WAG, and Z. Digital photographs from FI also have been examined. Curators at BOL, GOET, LD, MANCH, MSTR, SAM, TDC, W, WRSL, and WU kindly responded to our request for a loan, but were unable to find, or could not send, the specimens we sought.

For the scanning electron microscopy study (SEM), samples were mounted to aluminium stubs, coated with $40-50 \mathrm{~nm}$ gold, and examined with a HITACHI S-3000 N (Tokyo, Japan) scanning electron microscope at $16 \mathrm{kV}$.

Seventy quantitative characters were recorded and measured using a Mitutotyo CD-15CD digital calliper (Tokyo, Japan) for at least ten specimens of each species, which is considered to be a representative number of samples to record the full morphological range of a species (Rico and Bachman 2006). Each character was analyzed for its mean, median, range, standard deviation, and significance using the STATISTICA package (www.statsoft.com). To represent the variability of each descriptor within each species, box-plots containing medians and percentiles were prepared.

Quantitative and qualitative characters were used in the key and descriptions. For the key the most discriminatory characters were inferred from box-plots.

Indumentum terminology and species descriptions follow a standard format used by Wieringa (1999) to represent all the relevant features in Caesalpinioideae genera. Label data from each specimen studied was recorded in a database from which reports and outputs were generated to produce a list of numbered collections, the representative material studied, and a file with coordinates used to produce distribution maps.

Where available, information on uses and vernacular names and language of the name is included. We also include available references for further information on these topics.

\section{RESUlts}

Morphology-HABIT-Daniellia species are deciduous or evergreen trees up to $45 \mathrm{~m}$ high with a straight cylindrical bole, without buttresses. Daniellia alsteeniana has been reported both to be leafless (Reitsma 1414) and evergreen (Gossweiler 11282).

INDUMENTUM-Only simple and uniseriate trichomes are found in Daniellia (Theobald et al. 1979). These unicellular trichomes are eglandular, of variable length $(0.2-1.6 \mathrm{~mm})$ and with a smooth surface. They are found in all species, are present on almost all organs (Fig. 1A), and are sometimes surrounded by crystalline deposits (Fig. 1B).

Twigs-In Daniellia alsteeniana, D. glandulosa, D. oblonga, D. pilosa, D. pynaertii, and D. soyauxii the twigs are pubescent when young. The presence of annular scars left by the caducous stipules and appearing like growth-rings along the twigs is a distinctive feature of the genus.

LEAVES-Leaves are alternate, variable in size and in number of leaflets. Stipules are fused into a single intrapetiolar stipule that is accrescent and caducous to leave a scar. In early foliage development the bud scales are ovoid and envelop the young shoots; later the stipules become oblong and foliaceous, as seen in Daniellia glandulosa, D. ogea, D. soyauxii, and $D$. thurifera. The petiole is pulvinate; the pulvinus may be pubescent or glabrous. The leaf rachis is subterete and slightly channeled at the base, becoming quadrangular distally. A pair of sunken glands are present on the leaf rachis at the insertion points of all pairs of leaflets in D. glandulosa, D. oblonga, D. ogea, D. oliveri, and D. pynaertii, but are present only between the basal and lower leaflet pairs in $D$. alsteeniana, D. klainei, and D. thurifera. Leaf rachis glands are absent in $D$. soyauxii and in D. pilosa (except in the type collection of the latter in which we have found a small pair of glands
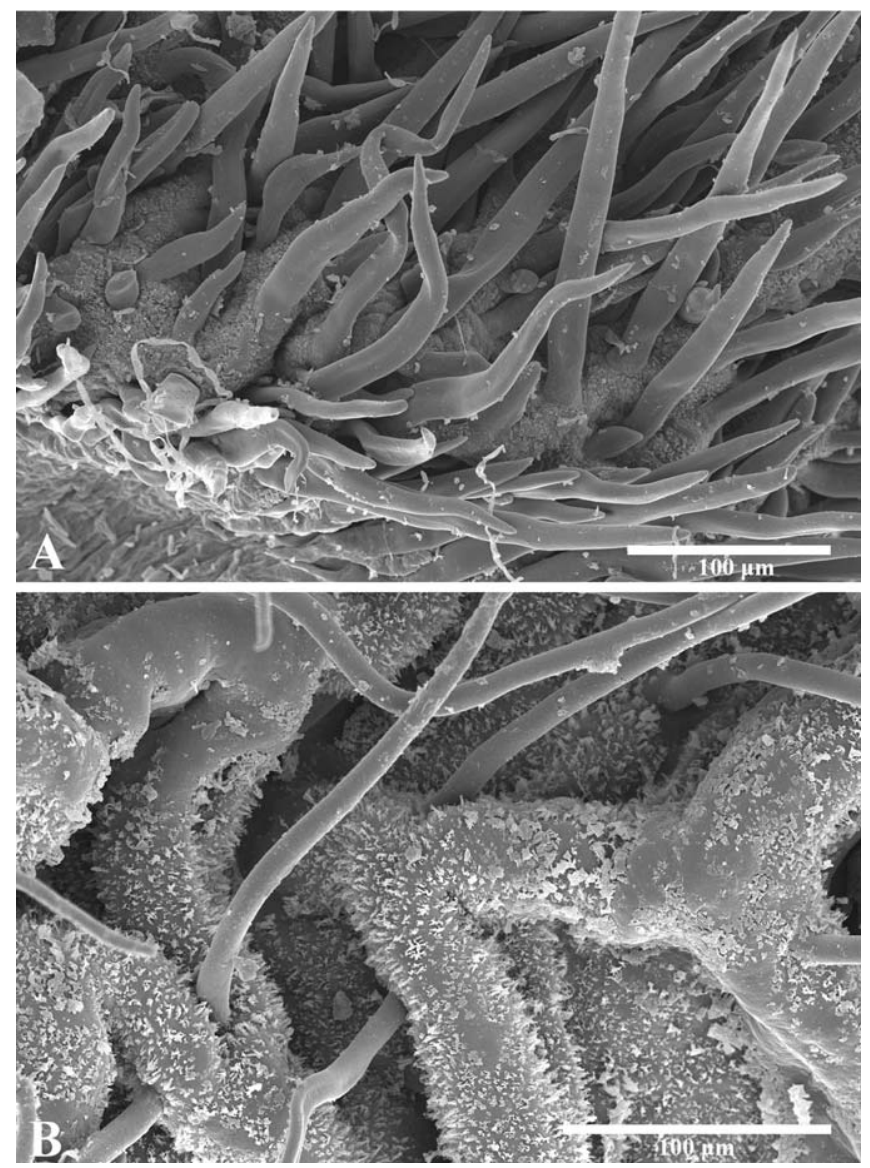

FIG. 1. SEM photographs of the trichome types found in Daniellia. A. Pedicel of D. pilosa showing: simple and uniseriate trichomes (Wieringa $\mathcal{E}$ van Poll 1462, WAG-110749). B. Petiolule of D. alsteeniana showing small trichomes surrounded by crystalline deposits (Reitsma 1414, MA-367516).

between the basal leaflet pair). Leaflets are pulvinate, usually all in opposite pairs (basal pairs are sometimes subopposite), acuminate, asymmetric at the base (the proximal side narrower than the distal side). Leaflet size and shape is variable and appears to vary with the age of the tree. Consequently, we consider leaflet size and shape unsuitable as charcters on which to base species delimitation; likewise the wide range in the density and position of translucent gland dots on leaflets does not aid species recognition.

INFLORESCENCE-The primary inflorescence unit is a raceme, a number of which are compounded into a compound or double compound raceme (Wieringa 1999), which comprises a principal axis and simple lateral branches, except in Daniellia ogea, D. pilosa, and D. pynaertii where the lateral branches divide again. In D. alsteeniana and D. klainei the lateral branches are comparatively longer than in other species. Flowers are spirally arranged. The indumentum of the inflorescence rachis is velvety, formed of long hairs in D. pilosa and $D$. soyauxii, tomentose in D. ogea, glabrous in D. thurifera, and from pubescent to glabrous in the remaining species.

BRACTS AND BRACTEOLES-The bracts and bracteoles are caducous. The fallen bracteoles leave a scar usually at the midpoint along the pedicel, except in Daniellia glandulosa and D. oliveri in which the scar is situated below the midpoint. Some species have bracteoles with pubescent margins and apex (D. alsteeniana, D. klainei, and D. pynaertii). Bracteoles of D. oliveri have a tuft of hair at the apex, while in D. ogea and D. soyauxii 
they are pubescent on their adaxial surface. Bracteoles of D. glandulosa, D. oblonga and D. thurifera have not yet been observed.

CALYX - The sepals are imbricate and have translucent dots which are more clearly visible in the zones of sepal overlap. In Daniellia alsteeniana, D. glandulosa, D. oblonga, D. pynaertii, and $D$. soyauxii the sepals are slightly pubescent along the margins and toward the apex. In D. klainei, D. oliveri, and D. thurifera the sepals have a ciliate margin, but are otherwise completely glabrous; sepals of D. ogea are pubescent and those of $D$. pilosa are densely velvety.

COROLLA-Flowers are zygomorphic and petal color ranges from blue to purplish to white. The information on petal and sepal color is sparse and lost when specimens are dried. Daniellia oliveri (subgen. Paradaniellia) usually has one large lateral petal and four reduced petals. All other species have two large lateral petals, one medium sized adaxial petal and two reduced abaxial petals. Petal development is one of the characters on which the subgeneric division is based. In Daniellia subgenus Daniellia the lateral petals are larger than the adaxial petal, except in $D$. thurifera. The lateral petals are pubescent at the base and apex of the inner surface in D. alsteeniana and D. glandulosa, but velvety to villous in the other species of the subgenus.

Stamens and Pollen-The two Daniellia subgenera are also differentiated by their degree of staminal fusion and the stamen filament indumenta. While all Daniellia species have ten stamens, those in subgenus Daniellia have nine united at the base into a short tube and the adaxial one free; all have slightly pubescent to villous filaments. In subgenus Paradaniellia all stamens are free and the filaments are glabrous or at most with one or two hairs at the base (Fig. 2A-B).

Daniellia pollen is uniformly isopolar and spherical or nearly so. Generally, the apertures are tricolporate with granular aperture membranes and the exine is perforate with a rugulate and granular ornamentation (Banks and Klitgaard 2000; Fig. 2C-F).

GyNOECIUM-The ovary is usually oblong to lanceolate but may be rhombic. The indumentum of the ovary and style varies from glabrescent to glabrous in Daniellia glandulosa, D. klainei, D. oblonga, D. oliveri, and D. thurifera, or has a few scattered hairs along the ovary sutures in D. alsteeniana, D. pynaertii, and D. soyauxii, or is densely pubescent in $D$. ogea and $D$. pilosa. Stigmas are glabrous and have a rough surface.

FRUIT-The pod dehisces along both sutures into two valves. The solitary seed has a smooth testa and is dispersed while still attached by the funicle to the exocarp of one valve [the dispersal unit is like a pseudosamara resulting in a mechanism which Ulbrich (1932) named as "PendelSchrauben-flieger" (pendulum helicopter)]. Pod shape is always somewhat asymmetric and varies from oblong-falcate (D. alsteeniana and D. klainei), \pm oblong with a straight side combined with a falcate one (D. thurifera and D. pynaertii), oblong (D. oblonga) to elliptic (D. pilosa). The presence of a small apical beak distinguishes $D$. soyauxii from $D$. ogea. Most species have entirely glabrous pods, but D. ogea, D. pilosa, D. pynaertii, and $D$. soyauxii have hairs along their sutures. The larger pod size of D. alsteeniana and D. klainei aids identification (Fig. 3M).

SEEDS—Seeds are usually dark brown, smooth and oblong, oblong-elliptic or obovate-elliptic. Seeds are of similar size throughout the genus with the exception of D. klainei with comparatively longer seeds and $D$. oliveri with seeds obovateelliptic and thicker than in the other species. The seed coat is smooth at $30 \times$ magnification and has a spongy tegmen in transverse section (Fig. 2G-H).
Pollination-Information on the pollination of Daniellia is limited although various pollination syndromes are alluded to, e.g. the flowers of $D$. oliveri are reported to be visited by bees (Chapman 3017) whereas other authors (Timberlake et al. 2007) have suggested that the flowers are visited by bats. Wieringa (1999) reported that the flowers of D. soyauxii and $D$. pilosa are visited by sunbirds. Commonly, the flowers are said to have a sweet scent.

Phenology-Information on phenology is sparse in Daniellia species and where known is discussed under the appropriate species in the taxonomic treatment.

Habitat and Distribution-Daniellia is distributed in tropical and subtropical Africa and is particularly species-rich in the Guineo-Congolian region. Daniellia oliveri, the most widespread species, grows in wooded grassland (savannah) and deciduous forest from Senegal to South Sudan and Uganda. Daniellia alsteeniana also grows in wooded grassland, but south of the equator from Gabon to western Angola and extending to eastern Zambia. Daniellia oblonga is found in forests from Cameroon, Equatorial Guinea, and Gabon. Daniellia thurifera grows in coastal areas of West tropical Africa and D. pyneartii in Central Africa; D. ogea grows from Senegal to Gabon always near the sea and rivers. Daniellia glandulosa is only known from Cameroon, D. soyauxii is restricted to Cameroon and Gabon, and D. pilosa has been recorded from Congo (Brazzaville), Congo (Kinshasa) and Gabon.

\section{TAXONOMIC TREATMENT}

DANIElliA Benn., Pharm. J. Trans. 14: 252. 1854.-TYPE: D. thurifera Benn.

Cyanothyrsus Harms, Engler \& Prantl, Nat. Pflanzenfam., Nachtr. II-IV, 1: 197. 1897.-TYPE: C. oblongus (Oliv.) Harms.

Small to large trees. Leaves alternate, pulvinate, paripinnate, 4-11-jugate; stipules accrescent, foliaceous and caducous, leaving annular scars; petiole channeled proximally, becoming almost quadrangular distally, usually with a pair of glands on upper side at the point of insertion of each pair of leaflets; petiolule pulvinate; leaflets generally opposite, basal leaflets sometimes subopposite, coriaceous, translucent gland dots present (either throughout the blade or sometimes restricted to the leaflet margins or near to the base of the midrib) and with one or two glands present near the midrib on the abaxial face, apex acuminate, base asymmetric. Inflorescence a compound or double compound raceme, flowers spirally arranged; bracts caducous, about midway along the pedicel, convex, protecting the flower in bud but falling before anthesis, leaving a scar. Receptacle elongated, ciliate within. Sepals 4, imbricate, with translucent dots. Petals 5, differing in size and shape, adaxial petal large or medium-sized and either one lateral petal large or medium-sized and the other three petals reduced in size or both laterals large or medium-sized and only the abaxial petals reduced in size. Stamens 10, free, or 9 of them united at the base into a short tube; anthers dorsifixed, opening by longitudinal slits. Ovary stipitate, the stipe adnate to the receptacle, style long, accrescent, stigma capitate. Pods woody, compressed, dehiscing into 2 valves, endocarp coriaceous, separating from the exocarp, seed solitary, with a smooth testa, attached near the distal end of the pod, dispersed together with the entire endocarp while remaining attached to the exocarp of one valve of the pod. 


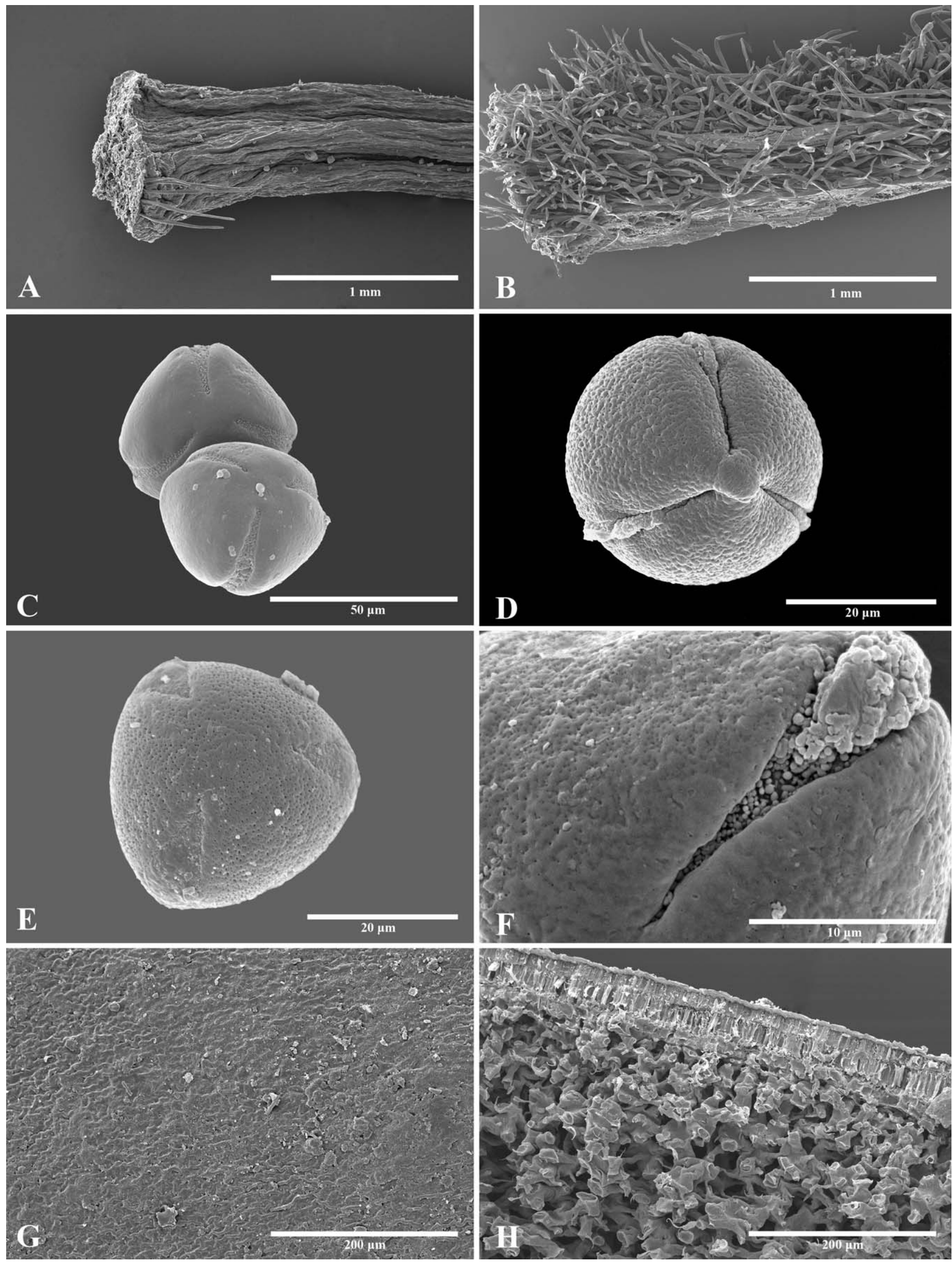

Fig. 2. SEM photographs of stamen filaments, pollen, and seed features in Daniellia. A. Base of the stamen filament in D. oliveri (Wilde \& Wilde-Duyfjes 4618, WAG-0110766). B. Base of the stamen filament in D. thurifera (W. J. Wilde 625, WAG-09575). C. Pollen grain of D. alsteeniana (Callens 4616, M). D. Pollen grain of D. oliveri (Jongkind \& Nieuwenhuis 1953, UPS). E. Pollen grain of D. thurifera (W. J. Wilde 625, WAG-09575). F. Pollen aperture of D. thurifera (W. J. Wilde 625, WAG-09575). G. Seed testa of D. ogea (Carvalho 3789, MA-512442). H. Seed tegmen in transversal cut of D. ogea (Carvalho 3789, MA-512442). 


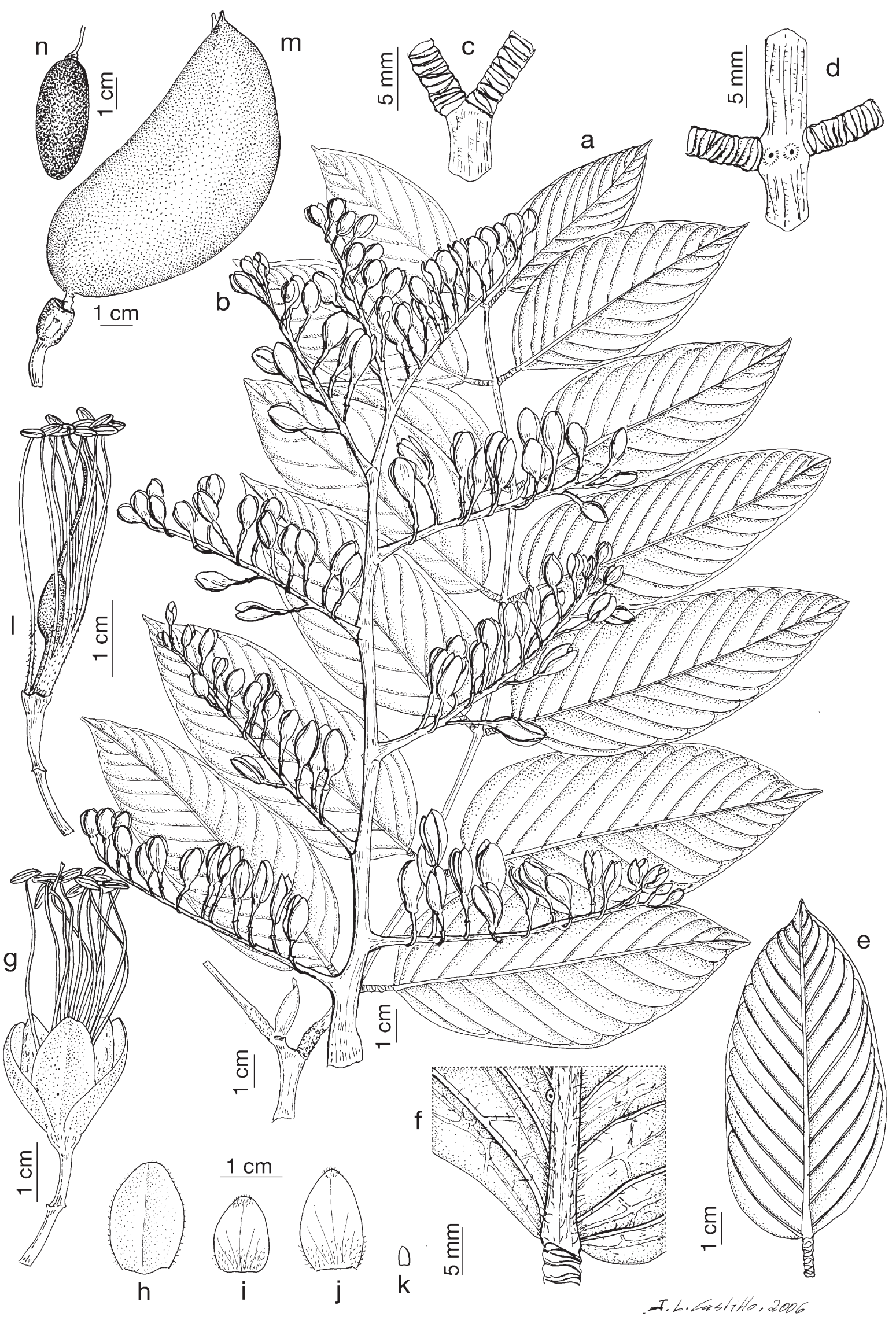

FIg. 3. Daniellia alsteeniana. a. Twig with leaves. b. Inflorescence. c. Insertion of apical pair of leaflets. d. Insertion of basal pair of leaflets with paired glands. e. Leaflet, abaxial surface. f. Leaflet gland, abaxial surface. g. Flower. h. Sepal seen from exterior. i. Adaxial petal seen from exterior. j. Lateral petal seen from exterior. k. Abaxial petal seen from exterior. 1. Flower without perianth. m. Pod. n. Seed. [based on: a, Reitsma 1414 (MA-367516); b, e, f, m, n, Carriso \& Mendoça 537 (BM-883762); c, d, Liben 2944 (M-99156); g-l, Devred 1849 (K)]. 


\section{Key to the Species of Daniellia}

1. Petals normally one, large, (7-)10-12 mm long, and 4 reduced, $1-1.5(-3) \mathrm{mm}$ long (rarely 2 large petals, the second one up to $8 \mathrm{~mm}$ long, and 3 reduced); stamen filaments free, glabrous (rarely a few hairs at the base);

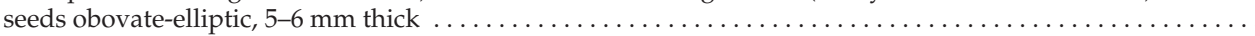

1. Petals two large, 6-22 $\mathrm{mm}$ long and one medium-sized, $4-16 \mathrm{~mm}$ long and 2 reduced, $0.8-5 \mathrm{~mm}$ long; stamen filaments united at the base, pubescent to villous at least in the lower third of their length; seeds oblong to oblong-obovate, $1-5 \mathrm{~mm}$ thick (Fig. $3 \mathrm{~N}$ )

2. Gland small, crater-shaped, present on the abaxial leaflet surface, at the junction of a lateral vein with the midrib,

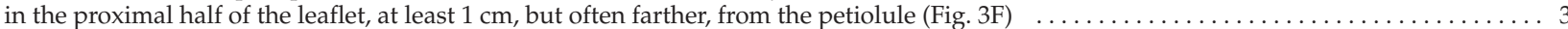

3. Leaf rachis with a pair of glands at the insertion of each pair of leaflets; lateral branches of the inflorescence $4-6 \mathrm{~cm}$ long; bracteole insertion scar in the lower half of the pedicel $\ldots \ldots \ldots \ldots \ldots \ldots \ldots \ldots \ldots \ldots \ldots \ldots \ldots \ldots$. . . D. glandulosa

3. Leaf rachis with a pair of glands only at the insertion of basal pairs of leaflets (rare in upper ones); lateral branches of the inflorescences $6.5-11.5 \mathrm{~cm}$ long; bracteole insertion scar in the upper half of the pedicel $\ldots \ldots \ldots \ldots \ldots \ldots \ldots \ldots \ldots \ldots \ldots$

4. Leaflets glabrous on the lower surface; petiolules usually thickened by glands; pedicel glabrous; sepals (5-)8-10(-12) mm wide; filaments pubescent along the basal two-thirds of their length $\ldots \ldots \ldots \ldots \ldots \ldots \ldots \ldots$....... 3. D. klainei

4. Leaflets tomentose to villous on the lower surface, mainly along the midrib; petiolules not thickened by glands; pedicel pubescent to glabrescent; sepals 9-15(-23) mm wide; filaments pubescent along the basal third of their length .. 1. D. alsteeniana

2. Gland(s) one or two, small, crater-shaped, present on the abaxial leaflet surface, one at the junction of the first or second

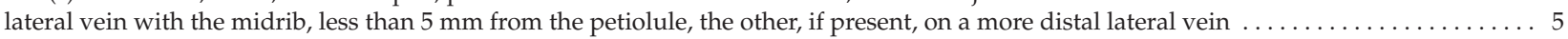

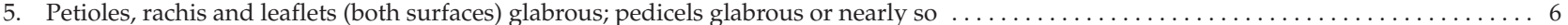

6. Rachis with a pair of glands at the insertion of each pair of leaflets; inflorescence rachis slightly pubescent; pedicels glabrescent; adaxial petal pubescent on both faces $\ldots \ldots \ldots \ldots \ldots \ldots \ldots \ldots \ldots \ldots \ldots \ldots \ldots \ldots \ldots \ldots \ldots$. . . . oblonga

6. Rachis with a pair of glands only at the insertion of the basal pair of leaflets (rarely also in the second one); inflorescence rachis glabrous; pedicels glabrous; adaxial petal \pm pubescent on the outer surface

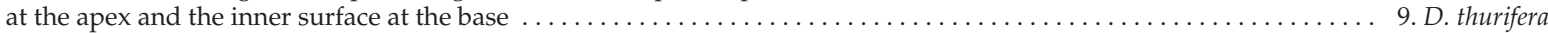

5. Petioles, rachis and leaflets pubescent to moderately pubescent (mainly on midrib on the lower surface of the leaflet); pedicels velvety pubescent, or if glabrescent then leaflet midrib abaxial face patently pubescent (D. pynaertii) $\ldots \ldots \ldots \ldots \ldots \ldots \ldots$

7. Leaf rachis with a pair of glands at the insertion of each pair of leaflets; pedicel $12-20(-23) \mathrm{mm}$ long $\ldots \ldots \ldots \ldots \ldots \ldots \ldots$

8. Leaflet midrib glabrous (rarely with few hairs on the lamina base near petiolule); pedicel velvety pubescent; sepals 5-9 mm wide, pubescent on their external face, except where they overlap;

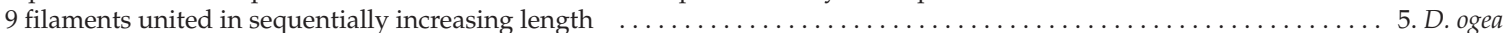

8. Leaflet midrib pubescent (rarely glabrescent); pedicel glabrescent; sepals $8-14 \mathrm{~mm}$ wide, sparsely pubescent on margins and apex; 9 filaments united at the base $\ldots \ldots \ldots \ldots \ldots \ldots \ldots \ldots \ldots \ldots \ldots \ldots \ldots \ldots \ldots \ldots \ldots$ 7. D. pynaertii

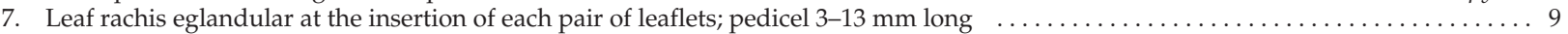

9. Leaflet midrib glabrous; inflorescence a compound raceme with 5-6 lateral branches; sepals glabrous except for a few hairs on the margins and apex; filaments 1 free and 9 united in a sequentially

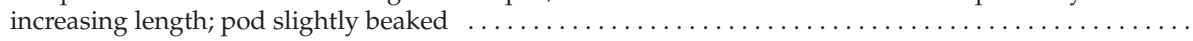

9. Leaflet midrib pubescent abaxially; inflorescence a double compound raceme with 9-13 lateral branches; sepals velvety pubescent on external face; filaments 1 free and 9 united at the base; pod rounded at the apex 
apex, inserted at the midpoint of the pedicel. Receptacle $4-7.5(-8) \times 5-7(-8) \mathrm{mm}$, ciliate within; pedicel plus receptacle 21-27 mm long; flower bud 6-8(-10) mm wide. Flowers with dull purple sepals and white to yellowish-green petals. Sepals 4, (14-)18-23 × 9-15(-23) mm, oblong, slightly pubescent along the margins and at the apex, small gland dots present. Petals 5; adaxial petal 10-15 × 6-9 (-11) mm, oblong, pubescent to glabrescent within, pubescent externally at the base and apex, gland dots absent or present; lateral petals (11-)14-17(-22) × 9-13 mm, oblong, gland dots absent or present, apex pubescent on both surfaces, base internally slightly pubescent externally pubescent; abaxial petals (0.8-) $2.3-4 \times 0.8-1.7(-3) \mathrm{mm}$, ovate-elliptic, glabrous or with a few hairs at the apex. Stamens 10, filaments (13-)22-36(-46) mm long, 9 united at the base for $1.2-5.6 \mathrm{~mm}$, pubescent at least on the lower third; anthers (2.4-)3.4-4.1 mm long. Ovary 7.5-8.5(-11) $\mathrm{mm}$ long, lanceolate-rhombic, glabrous to slightly pubescent (mainly along the margins), smooth, gland dots absent, stipe (5-)6-9 mm long, glabrous to pubescent; style 20-22 mm long, glabrous or with few scattered hairs; stigma rounded. Pod 9.5-10.5 × 3.5-6 cm, oblongfalcate, glabrescent, stipe 8-22 mm long, pedicel $24-26 \mathrm{~mm}$ long, receptacle thickened (in fruit). Seeds (24-)26-38(-43) $\times$ 15-22 × 3-5 mm, oblong-obovate, smooth, dark brown; funicle $12-18 \mathrm{~mm}$ long. Figure 3.

Phenology-Flowering is recorded from April to September; fruiting from March to November.

Distribution and Habitat-Gabon, Congo (Kinshasa), Angola, and Zambia; clear and dry forest, savannah lands; 350-1,400 m. Figure 4.

Vernacular Names-Congo (Kinshasa): Dilula, Nlombe, Mundumbu (Kiluba), Mufumangono, Mulombe (Kiyaka), Mutobo (Tshiluba), Mutumpo (Kiluba), Muvumagoma, Tshintschimbu (Tshiluba).

\section{Uses-Production of gum resin.}

Representative Specimens Examined-ANGOLA: Moxico, Teixeira de Sousa, $10^{\circ} 42^{\prime} \mathrm{S}, 22^{\circ} 14^{\prime} \mathrm{E}$, Andrada 100 (BR, COI, LISC); Lunda Sul, AltoCuilo, río Cavuemba, $10^{\circ} 2^{\prime}$ S, 19³0' E, Barros Machado VI.54-140 (LISC); Lunda Norte, Mungo (Carumbo), confluencia Luxico com o Luéle, $7^{\circ} 44^{\prime}$ S, 1956' E, Carisso $\mathcal{E}$ Mendoça 537 (BM, COI, FI-photo, M, MO); Lunda Sul, Saurimo, $9^{\circ} 39^{\prime}$ S, 20²4' E, Gossweiler 14088 (B, BM, K, P, US); Lunda Norte, entre Maludi e Chiafua, Mendes dos Santos 1605 (LISC); Cuanza Norte, entre Pambos de Sonhe e Camabatela, Raimundo, Matos \& Maia 400 (BR).

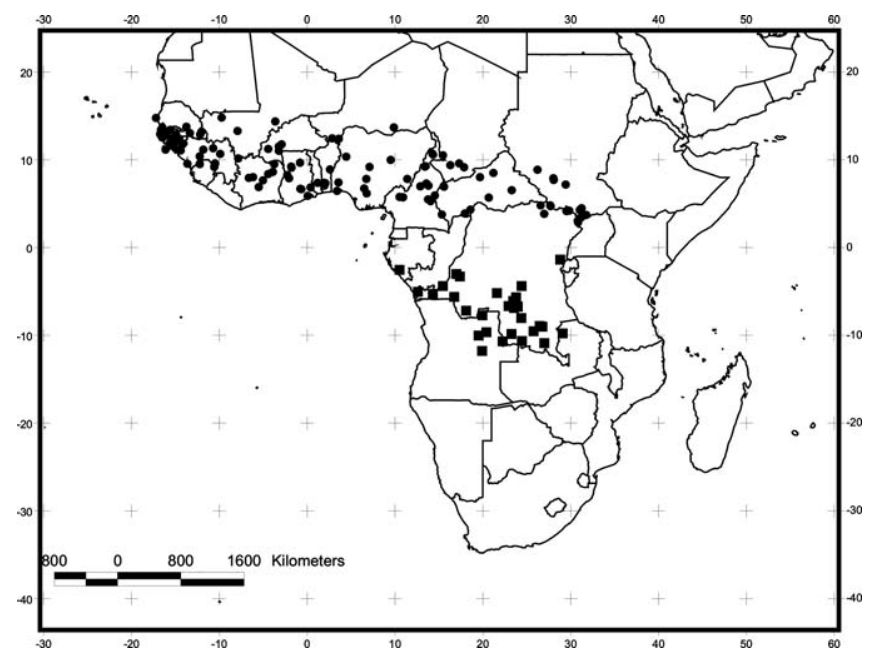

FIG. 4. Distribution of Daniellia alsteeniana (squares) and D. oliveri (circles).
CONGO (Kinshasa): Village of Malela, about 50-60 km south of Pania Mutombo, $5^{\circ} 40^{\prime} \mathrm{S}, 23^{\circ} 45^{\prime} \mathrm{E}$, Becquaert 19 (GH, BR, K); Kalibala, $7^{\circ} 12^{\prime} \mathrm{S}$, $18^{\circ} 4^{\prime}$ E, Callens 3323 (BR); Bandundu, Popokabaka, Muniungu, 539' S, $16^{\circ} 45^{\prime}$ E, Callens 4616 (BR, Z); Kasai Oriental, Kamponde, 642' S, 22 ${ }^{\circ} 56^{\prime}$ E, Declercq 2 (BR); Katanga, Lufira, 1054' S, 265'르. E, Delvaux 224 (BR, K); Kabongo, Delvaux 790 (BR, K); Kinshasa, Kahemba Kwanbo, Mikondo, $4^{\circ} 24^{\prime} \mathrm{S}, 1^{\circ} 26^{\prime}$ E, Devred 1849 (BR, K, LISC); Sud Kivu, Masisi, Kahemba, $1^{\circ} 23^{\prime}$ S, $28^{\circ} 48^{\prime}$ E, L. Dubois 1491 (BR, WAG); Equateur, Ikusama, route Kwango-Wamba, Germain 2476 (BR, K); Kasai Oriental, région de Lubefu,

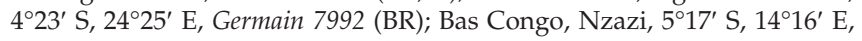
Huart 66 (BR); Kahemba, Jernander 68 (BR); entre la Cohduala et Kiwaka, Lebrun 157 (BR); Ngoma, Lecomte 9/194 (P); Route Bakwanga-Bakwasumpi (Territoire Bakwanga), Liben 1767 (BR); Kele (territoire MweneDitu), Liben

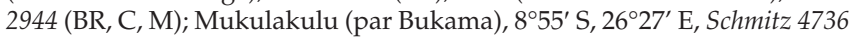
(BR); Katanga, Mukulakulu, 9 ${ }^{\circ} 33^{\prime}$ S, $25^{\circ} 47^{\prime}$ E, Troyer 117 (BR); P. N. de L'Upemba, 9 S, 2645' E, Witte 3889 (BR, K); without locality, km 201 T.D., Ritschard 1792 (BR).

GABON: Nyanga, rainforest in the Doudou Mountains, ca. $35 \mathrm{~km} \mathrm{SW}$ of Doussala, 2³2' S, 10³0' E, Reitsma 1414 (C, MA, WAG).

ZAMBIA: Kawambwa, 947' S, 295' E, Fanshawe 4344 (K).

Discussion-Daniellia alsteeniana is restricted to central and south central Africa. The species may be distinguished by its comparatively longer lateral inflorescence branches and the presence of a gland on the abaxial face of the leaflet, situated on the narrower side of the lamina near the midrib and located 1-3 cm from the petiolule (Fig. 3F). Although these two characters are shared with $D$. klainei, the presence of pubescence either on the petiolules, rachis, leaflets and/or the inflorescence of D. alsteeniana can be used to separate it from D. klainei which is completely glabrous (Table 1). However, we have observed some variation in the indumentum within Daniellia alsteeniana; some specimens have glabrous leaves and inflorescences (Callei 4616, Andrada 100), and could be confused with $D$. klainei, but D. alsteeniana has larger sepals and petals than D. klainei. In addition, in D. klainei the leaflets are usually larger and the petiolules are more commonly thickened by glands than in D. alsteeniana. Another feature that can assist in distinguishing $D$. alsteeniana are slightly pubescent staminal filaments with indumentum present only in the proximal third of their length (Fig. 3L), while other species (except D. oliveri, species in which the filaments are glabrous), are densely pubescent along two-thirds of the length of the filaments (Table 1).

Although Daniellia alsteeniana is for the most part, morphologically uniform, in some specimens (Carriso $\mathcal{E}$ Mendoça 537 , Simon $30 B$ and Dubois 1491) we observed that the flower receptacle was thickened in fruit, reaching $2-3 \mathrm{~cm}$ in diameter by the presence of numerous glands.

Daniellia alsteeniana and D. oliveri are the only two species of dry forest and savannah woodland. The former is found south of the equator and is the most meridional species of the genus; while the second is found in savannah habitats south of Sahel (Fig. 4). Although the species share a preferred habitat, morphologically they are distinct. Daniellia alsteeniana belongs to Daniellia subgen. Daniellia and D. olivieri constitutes the monotypic Daniellia subgen. Paradaniellia (Table 1).

When Duvigneaud (1949, p. 28) described D. alsteeniana he stated: "Typus Duvigneaud 950a" but did not indicate at which herbarium the specimen was deposited. Léonard (1950, p. 114) said that the type material of this species was stored in "Herb. Brux." and consequently selected Duvigneaud 950a (Herb. Brux.) as the lectotype. Here we clarify that designation as during the course of this study, Duvigneaud 950a was located at BRLU.

2. Daniellia glandulosa Estrella, sp. nov.-TYPE: CAMEROON. Colline Ngwon (38 km Est de Kribi), 18 April 1968, Letouzey 9356 (holotype: P!). 


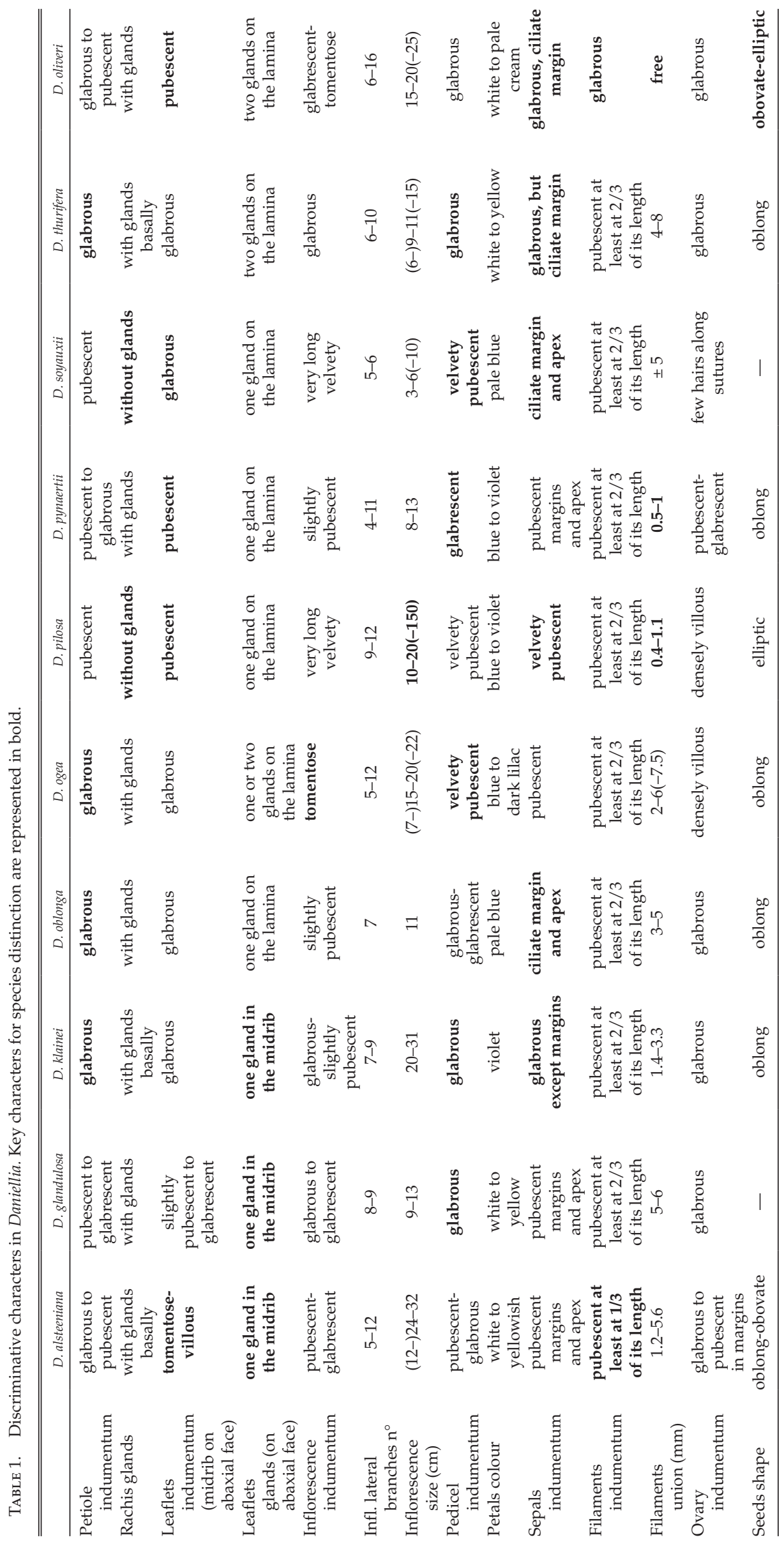


Facillime distinguitur a Daniellia alsteeniana et D. klainei foliolorum glandulis basalibus floccis pilorum circumdatis, inflorescentia breviore (9-13.4 cm longa nec, ut in aliis duabus, (12-) 20.6-32 cm) atque bracteolarum, caducarum, cicatricula infra medium pedicellum nec supra eum locata.

Tree ca. $120 \mathrm{~cm}$ dbh. Twigs and branches glabrescent to slightly pubescent on young parts, with marked bud-scales scars clearly visible on the vegetative and inflorescence branches. Leaves 31-40 × 25-35 cm, (5-)6-7-jugate, largest leaflet situated above the midpoint of the leaf; stipules only seen on young branches $6.5-11 \times 2.5-3.5 \mathrm{~mm}, \pm$ oblong, revolute, glabrescent to pubescent externally, accrescent, up to 7-21 $\times$ 1-2 cm, caducous; petiole 23-32 mm long, terete, shallowly channeled, slightly pubescent to glabrescent, with a pair of small rounded glands surrounded by a tuft of hairs at the point of insertion of the basal pair of leaflets; petiolules $4.7-10 \mathrm{~mm}$ long; rachis 18-25 cm long, subterete and shallowly channeled at the base, becoming quadrangular distally, glabrous or glabrescent, with a pair of glands surrounded by a tuft of hairs at the point of insertion of each pair of leaflets, terminating in a small scale $0.2-2 \mathrm{~mm}$ long, glabrous; leaflets subopposite basally, opposite distally, coriaceous to papyraceous, margin undulate, mucronate, with 16-21 pairs of main lateral veins, densely covered with translucent gland dots, glabrous on the adaxial face, and slightly pubescent to glabrescent on the abaxial face, the indumentum, when present, mainly along the midrib, crateriform gland present on the lower surface on the narrower side of the lamina near the midrib, $1-1.5 \mathrm{~cm}$ from the petiolule, midrib prominent on the abaxial face, slightly channeled, petiolule more or less quadrangular, glabrescent; basal leafleet $8.5-9.5 \times 3.5-4 \mathrm{~cm}$, oblong, apex acuminate, acumen $2-4 \mathrm{~mm}$ long, base rounded and slightly asymmetric; apical leaflet $12-17 \times 4.5-5 \mathrm{~cm}$, oblong, apex acuminate, acumen 1-4.5 mm long, base asymmetric; largest leaflet 14-17.5 × 4-5.5 cm, oblong, apex acuminate, acumen $4.7-7.7 \mathrm{~mm}$ long, base rounded and asymmetric. Inflorescence a compound raceme, 9-13 cm long, peduncle 2-15 $\mathrm{mm}$ long, rachis glabrous or glabrescent with 8-9 lateral branches, each 4.5-6 cm long and 8-17-flowered; bracts caducous; pedicel 9-11 mm long, 2.4-2.7 mm diameter, glabrous, accrescent in fruit; bracteoles caducous, not seen, inserted below the midpoint of the pedicel. Receptacle $6.5-7 \times 3-4 \mathrm{~mm}$ wide, ciliate within; pedicel plus receptacle 17-19 mm long; flower bud $10 \mathrm{~mm}$ wide. Flowers with white to yellow petals. Sepals 4, ca. $13 \times 7 \mathrm{~mm}$, oblong, slightly pubescent along the margins and at the apex, small gland dots present. Petals 5; adaxial petal, ca. $14 \times 10 \mathrm{~mm}$, oblong, conduplicate, glabrous within, slightly pubescent externally at the apex, a few gland dots present; lateral petals ca. $15 \times 12 \mathrm{~mm}$ oblong, apex pubescent on both surfaces, base slightly pubescent internally and externally, gland dots absent or a few present; abaxial petals, up to $2 \times 1 \mathrm{~mm}$, ovate-elliptic, glabrous. Stamens 10, filaments 23-27 mm long, 9 united for 5-6 mm, pubescent at least along the lower two-thirds; anthers up to $3.5 \mathrm{~mm}$ long. Ovary $6.5 \mathrm{~mm}$ long, lanceolate-rhombic, glabrous, smooth, gland dots absent, stipe $5 \mathrm{~mm}$ long, glabrous; style $18 \mathrm{~mm}$ long, glabrous; stigma rounded. Pod oblong, glabrous (immature pod). Seeds not seen. Figure 5.

Phenology-Flowering is recorded in April. Letouzey reported on the herbarium label "flowering when new leaflets appear."

Distribution and Habitat-Cameroon; primary forest.

Vernacular Names-None reported.
Uses-None reported.

Discussion-Daniellia glandulosa is known only from the type but fortunately Letouzey $9356(\mathrm{P})$ is a complete collection including leaves, flowers, inflorescences and immature pods and has 12 duplicates. There is a second specimen with similar glands at the insertion of each pair of leaflets and on the abaxial face of the leaflet midrib but the collection from Equatorial Guinea [Lejoly 95T/L3.14 (BRLU), identified as Daniellia klainei], is sterile and without fertile characters cannot be authoritatively determined to species.

In Daniellia glandulosa the scar left by the caducous bracteoles is situated below the midpoint of the pedicel (nearer the pedicel base than in other species); this character is shared only with $D$. oliveri, a species from which it is clearly distinguished. Flowers of D. glandulosa are composed of one medium sized adaxial petal, two larger lateral petals, and two reduced abaxial petals whereas $D$. oliveri has one large petal and four reduced petals. Filaments of D. glandulosa are pubescent for at least two-thirds of their length with nine united into a short tube and one free, not glabrous (rarely few hairs at the base) and all free as in D. oliveri. Daniellia glandulosa has one gland on the abaxial face of the midrib about 1-1.5 cm from the petiolule; this character is shared with D. alsteeniana and D. klainei, and distinguishes these three species from the other species of Daniellia subgen. Daniellia (Table 1). Daniellia glandulosa is easily distinguished from D. alsteeniana and $D$. klainei by the presence of glands at each pair of leaflets surrounded by a tuft of hairs, whereas D. alsteeniana and D. klainei only have glands present at the insertion of the basal pairs of leaflets, not surrounded by a tuft of hairs. Furthermore, D. glandulosa has relatively short inflorescences, 9-13.4 cm long as compared to (12-)20-32 cm long of D. alsteeniana and D. klainei.

3. Daniellia klainei Pierre ex A. Chev., Bois du Gabon: 172. 1917.-TYPE: GABON. Environs d'Adouma, sur l'Orimbo, affluent de l'Ogooué, 29 July 1912, Fleury in Chevalier 26540 (lectotype designated by Léonard 1950: $116, \mathrm{P} !)$.

Daniellia klainei Pierre ex De Wild., Bull. Jard. Bot. État Bruxelles 7: 258. 1920, nom. illeg.-TYPE: GABON. environs de Libreville, "Fournit une résine copal", 1900 (flowers), 1901 (fruits), Klaine 1925 (lectotype designated here: BR!; isolectotypes: BM!, K!, NY!, P!).

Tree ca. $30 \mathrm{~m}$ tall. Twigs and branches glabrous, budscale scars patent but more densely so on the inflorescence branches than the vegetative branches. Leaves 29-43(-49) $\times$ 24-35(-39) cm, 4-7-jugate, largest leaflet situated below the midpoint of the leaf; stipules only seen on young twigs, (7-)10-17(-20) × (1-)2.5-6(-11) mm, oblong, revolute, glabrous to glabrescent with few hairs on the margin, accrescent, ca. $8.2 \times 1.1 \mathrm{~cm}$, caducous; petiole (19-)27-39(-90) $\mathrm{mm}$ long, (3-)4-6 mm diameter, \pm terete, glabrous, with a pair of small rounded glands just below first leaflets pair; petiolules (6-)8-11 mm long; rachis 11-20(-30) cm long, subterete and shallowly channeled at the base, becoming terete distally, glabrous or almost so, with a pair of glands at the point of insertion of the basal pairs of leaflets, terminating in a small scale 1-4 $\mathrm{mm}$ long; leaflets: basal pair subopposite, otherwise all opposite, coriaceous to papyraceous, margin slightly undulate, minutely mucronate, with 13-29 pairs of main lateral veins, translucent gland dots dense, glabrous on both faces, small crateriform gland present on the lower 


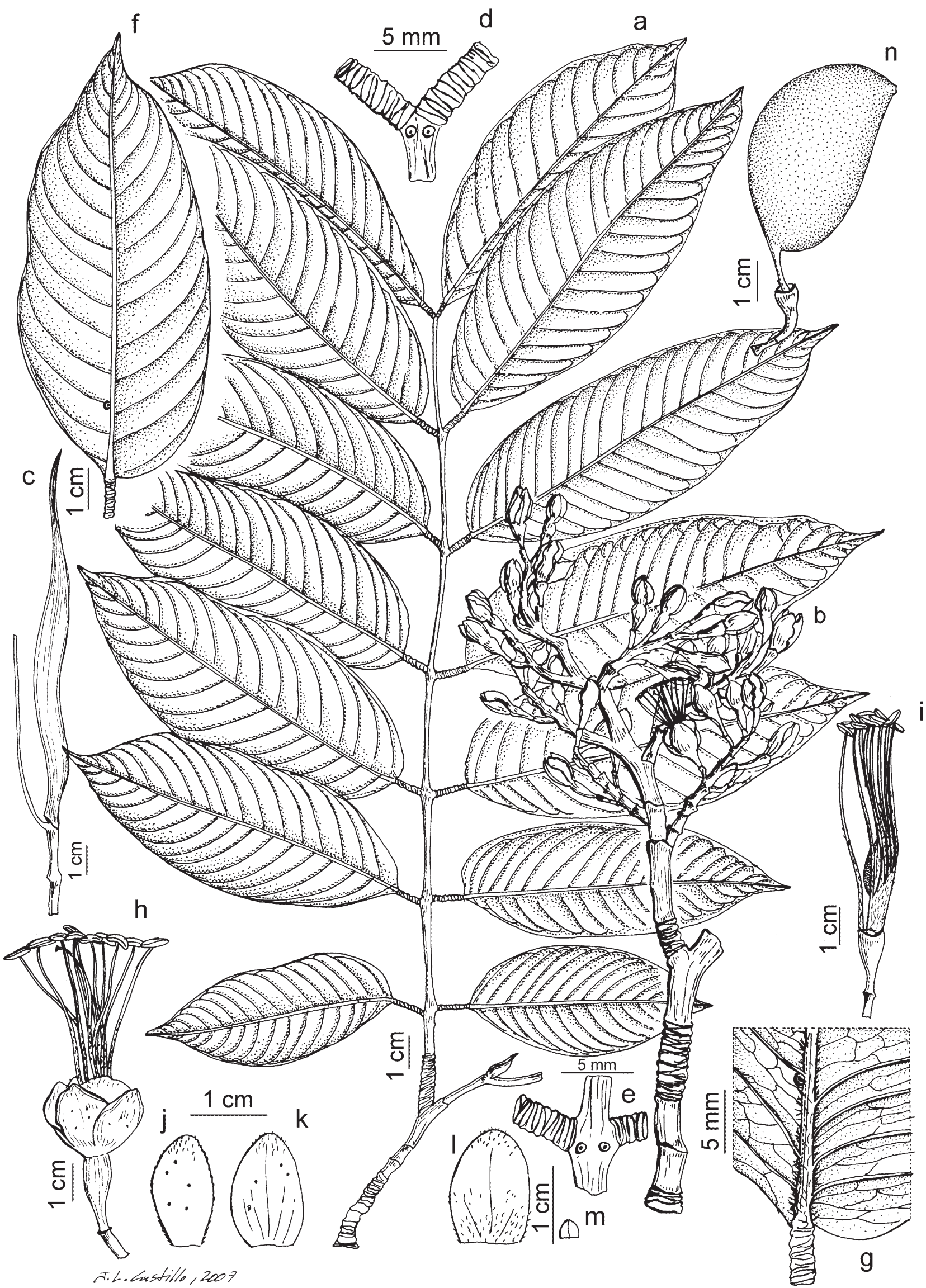

Fig. 5. Daniellia glandulosa. a. Twig with leaves. b. Inflorescence. c. Stipule. d. Apical pair of leaflets insertion. e. Insertion of basal pair of leaflets. f. Leaflet, abaxial surface. g. Leaflet gland, abaxial surface. h. Flower. i. Flower without perianth. j. Sepal seen from exterior. k. Adaxial petal seen from exterior. 1. Lateral petal seen from exterior. m. Abaxial petal seen from exterior. n. Pod. [based on: Letouzey 9356 (P)]. 
surface on the lateral side of the midrib, $2-5 \mathrm{~cm}$ from the petiolule, midrib prominent on the abaxial face, terete, sometimes shallowly channeled; basal leaflet (6-)10-12(-18) $\times$ (2.5-)4-7 cm, oblong-lanceolate, apex acuminate, acumen (2-)4-9(-10) mm long, base rounded and slightly asymmetric; apical leaflet $14.5-17(-21) \times 5-7(-11) \mathrm{cm}$, lanceolate, apex acuminate, acumen 3-6 mm long, base slightly asymmetric; largest leaflet (10-)16-22(-38) × (4-)5.5-7(-9) cm, oblong-lanceolate, apex acuminate, acumen (2.5-)5-7(-8) mm long, base rounded and asymmetric. Inflorescence a compound raceme, 20-31 cm long, peduncle 35-59 mm long, rachis glabrous to slightly pubescent with 7-9 lateral branches, each (4-)7$12(-14) \mathrm{cm}$ long and 8-29-flowered; bracts ca. $24 \times 12 \mathrm{~mm}$, caducous, elliptic, puberulous mainly on the outer face at the apex, inner face puberulous; pedicel (10-)15-18(-24) mm long, 1.5-2 mm diameter, slightly twisted at base, glabrous, accrescent in fruit; bracteoles, (8-)14-17 × 6-9(-17) mm, caducous, oblong-elliptic, puberulous mainly at the apex, inserted at the midpoint of the pedicel. Receptacle (2.5-)4-6 $\times 4-7 \mathrm{~mm}$, ciliate within; pedicel plus receptacle (13-)20-21(-26) $\mathrm{mm}$ long; flower bud 7-9(-10) mm wide. Flowers violet. Sepals 4, (10-)13-18(-19) × (5-)8-10(-12) mm, oblong-ovate, glabrous except along the margin which is slightly puberulous, with gland dots on external surface, rough. Petals 5; adaxial petal 9-11 × (4-)5-7 mm, oblong, velvety within, pubescent externally, a few scattered gland dots present; lateral petals $12-15 \times$ 7-12 mm, oblong-ovate, velvety within, pubescent on external face, with few gland dots on external face; abaxial petals 2.5-4.5 × 1.5-3 mm, ovate-elliptic, glabrous with few hairs at the apex. Stamens 10, filaments 30-35 mm long, 9 united at the base for $1.4-3.3 \mathrm{~mm}$, pubescent at least on the lower two-thirds; anthers 2.9-3.5 mm long. Ovary 7-10 mm long, lanceolate, glabrous, surface appearing slightly grainy due to presence of gland dots, stipe 4-6(-9) mm long, glabrous; style ca. $32 \mathrm{~mm}$ long, glabrous, slightly twisted, gland dots present; stigma rounded. Pod (8-)10-12 × 4-5 cm, oblong-falcate, glabrous, stipe $12 \mathrm{~mm}$ long (in fruit), pedicel $24 \mathrm{~mm}$ long (in fruit). Seeds 40-49(-52) × 19-20 × 2.5-3 mm, oblong, smooth, garnet; funicle $8-10 \mathrm{~mm}$ long. Figure 6.

Phenology-Flowering is recorded from August to December; fruiting from October to February.

Distribution and Habitat-Species found in Equatorial Guinea, Gabon, Congo (Kinshasa), and Angola (Cabinda); primary and secondary forest, bank of rivers and swampy areas; 10-250(-800) m. Figure 7.

Vernacular Names-Equatorial Guinea: Bisé (Fang), Nsu (Fang). Gabon: Lonlaviol (Fang), Mulingi, Sonlaviola (Pakuin). Congo (Kinshasa): Kitola Pombe. Angola: N'Tola-Kome.

Uses-None recorded.

Representative Specimens Examined-ANGOLA: Cabinda, Maiombe, Chiaca, 4 ${ }^{\circ} 53^{\prime}$ S, 12 12 34' E, Càmeira 213 (COI, LISC); Cabinda, Maiombe,

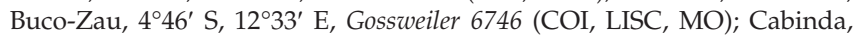
Maiombe, Chiaca, $4^{\circ} 53^{\prime}$ S, $12^{\circ} 34^{\prime}$ E, Missao Estudos Forestais Angola 353 (LISC); Cabinda, Buco Zau, entre Chion e Chiaca, $4^{\circ} 46^{\prime}$ S, $12^{\circ} 33^{\prime}$ E, Monteiro, Santos \& Murta 337 (BM, LISC).

CONGO (Kinshasa): Bas-Congo, Ganda-Sundi, $4^{\circ} 51^{\prime} \mathrm{S}, 1^{\circ} 51^{\prime} \mathrm{E}$, Donis 1326 (BR); Luki, Donis 1447 (BR), 1550 (K); Flamin, ou Lake, Flamigni 10341 (BR); Madula, Kisafu, Hauzer 13 (BR); Bas-Congo, Luki, Mayumbe, $5^{\circ} 38^{\prime}$ S, 133' E, Hombert 568 (BR, K), 576 (BR), 579 (BR, K); Léopoldville, Luki-Mayumbe, $5^{\circ} 38^{\prime}$ S, 134' E, Hombert 572 (K); Liki, Mahieu 72 (BR, K); Léopoldville, Boma, Luki, 538' S, 134' E, Maudoux 91 (BR, FI-photo, K); Kouilou, Sargos 32 (P); Bas-Congo, Léopoldville, Luki-Mayumbe, $5^{\circ} 38^{\prime}$ S, $13^{\circ} 3^{\prime}$ E, Wagemans 314 (BR, K, UPS); Bas-Congo, Luki, foret de la Ntosi, $5^{\circ} 38^{\prime} \mathrm{S}, 13^{\circ} 3^{\prime} \mathrm{E}$, Wagemans 694 (BM, BR, K).

EQUATORIAL GUINEA: P. N. de Monte Alén, transect de Monte Chocolate, $1^{\circ} 39^{\prime} \mathrm{N}, 10^{\circ} 19^{\prime} \mathrm{E}$, Lejoly 95T/160 (BRLU).
GABON: Tchibanga, Aubréville 178 (P); South of Lebamba, Bongolo, border of Louetsié river, $2^{\circ} 15^{\prime} \mathrm{S}, 11^{\circ} 30^{\prime} \mathrm{E}$, Breteler 7735 (WAG); OgoouéLolo, Makande surroundings, about $65 \mathrm{~km} \mathrm{SSW}$ of Booué. Makande, $0^{\circ} 41^{\prime}$ S, $11^{\circ} 55^{\prime}$ E, Breteler $\mathcal{E}$ al. 15223 (WAG); Estuaire, Libreville, $0^{\circ} 23^{\prime} \mathrm{N}, 9^{\circ} 27^{\prime} \mathrm{E}$, Fleury 33600 (B), 33603 (BR, P), 33606 (K, P), s. n. (P); Ikoy station, Gauchotte $1734(\mathrm{P}), 1737(\mathrm{P}), 1774(\mathrm{P})$; Libreville, $0^{\circ} 23^{\prime} \mathrm{N}, 9^{\circ} 27^{\prime} \mathrm{E}$, Klaine $415(\mathrm{P}), 1321$ (P), 1440 (BR, E, G, P); Tchibanga, Le Testu 1784 (BM, BR, E, G, K, LISC, MO, P); Ogooué-Maritime, Nguessi, 12' S, 853' E, Le Testu 2283 (A, BM, $\mathrm{BR}, \mathrm{E}, \mathrm{K}, \mathrm{P}, \mathrm{US})$; env. de Lambaréné, reserve du Zilé, $0^{\circ} 41^{\prime} \mathrm{S}, 10^{\circ} 17^{\prime} \mathrm{E}$, Normand 232 (P); Estuaire, Mbilagoné (Bilagone), $0^{\circ} 1^{\prime} \mathrm{N}, 9^{\circ} 48^{\prime} \mathrm{E}$, Thomson 12 (K); Haute Ngounié, Walker s. n. (K); Ngounié, Mission de St. Martin, Walker s. n. (P). Without locality: Gilbert 640 (BR); Tondeur 47 (BR).

Discussion-Daniellia klainei is one of the easiest species in the genus to recognize. It possess the largest leaves and leaflets in the genus (leaflets up to $27 \mathrm{~cm}$ in Maudoux 91), it has the largest seeds (up to $5 \mathrm{~cm}$ in Klaine 1925), and the petiolules are more commonly thickened by glands than in other species (Figs. 6A, C). The presence of one gland on the abaxial face of the midrib located $2-5 \mathrm{~cm}$ from the petiolule (Figs. 6C, D) is a character shared only with D. alsteeniana and D. glandulosa (Table 1). Notes concerning the separation of D. klainei from D. alsteeniana and D. glandulosa are included under those species.

The species shows considerable variation in the shape and texture of the leaf blade. Leaflets are usually oblong and coriaceous but may be lanceolate and papyraceous (Klaine 1440). This variation between collections may be attributable to age of the tree and/or position on the plant. Thus, shape and texture of the leaflets should not be used for species differentiation (Estrella et al. 2009).

When Chevalier (1916, p. 172) described Daniellia klainei, he stated: "Hab. - Environs d'Adouma, sur 1'Orimbo, BasOgooué, $\mathrm{n}^{\circ} 26540^{\prime \prime}$. Since the author indicated neither the collector nor the herbarium where the specimen was deposited, the identity of the holotype was not clear. Léonard (1950, p. 116) said that the type material of this species was stored in "Herb. Paris" and consequently selected Fleury in Chevalier $26540(\mathrm{P})$ as the lectotype.

De Wildeman (1920, p. 258) also published the name Daniellia klainei as a later homonym following an observation made by Pierre on a specimen of Klaine 1925 deposited in Brussels (BR). Breteler (2005) argued that the presence of drawings with descriptions made by Delphy of some of the species studied by Pierre should be considered as the correct place of publication for these species. We have not found any drawings of Klaine 1925 and therefore Pierre ex De Wild. is the correct authorship of the later homonym D. klainei. Since De Wildeman (1920, p. 258) did not designate a type for the name, here we select as lectotype Klaine 1925 (lectotype: BR; isolectotypes: BM, K, NY, P).

4. Daniellia oblonga Oliv., Fl. Trop. Afr. 2: 300. 1871. Cyanothyrsus oblongus (Oliv.) Harms, Engler \& Prantl, Nat. Pflanzenfam., Nachtr. II-IV, 1: 197. 1897.-TYPE: EQUATORIAL GUINEA. Bioko, Barter 2074 (lectotype designated by Léonard 1950: 99, K!; isolectotype: P!).

Tree ca. $40 \mathrm{~m}$ tall and ca. $150 \mathrm{~cm}$ dbh, with a cylindrical bole. Twigs and branches glabrescent, short white hairs on young parts, bud-scale scars clearly visible on the vegetative and inflorescences branches. Leaves 28-38 × 16-19 cm, 5-12-jugate; stipules only seen on young twigs $8-10 \times 3-5 \mathrm{~mm}$, ovoid, revolute, slightly pubescent on both surfaces, accrescent, ca. $126 \times 12 \mathrm{~mm}$, oblong, pubescent internally, glabrescent externally, caducous; petiole $26-43 \mathrm{~mm}$ long, terete, shallowly channeled, glabrous, with a pair of small rounded 


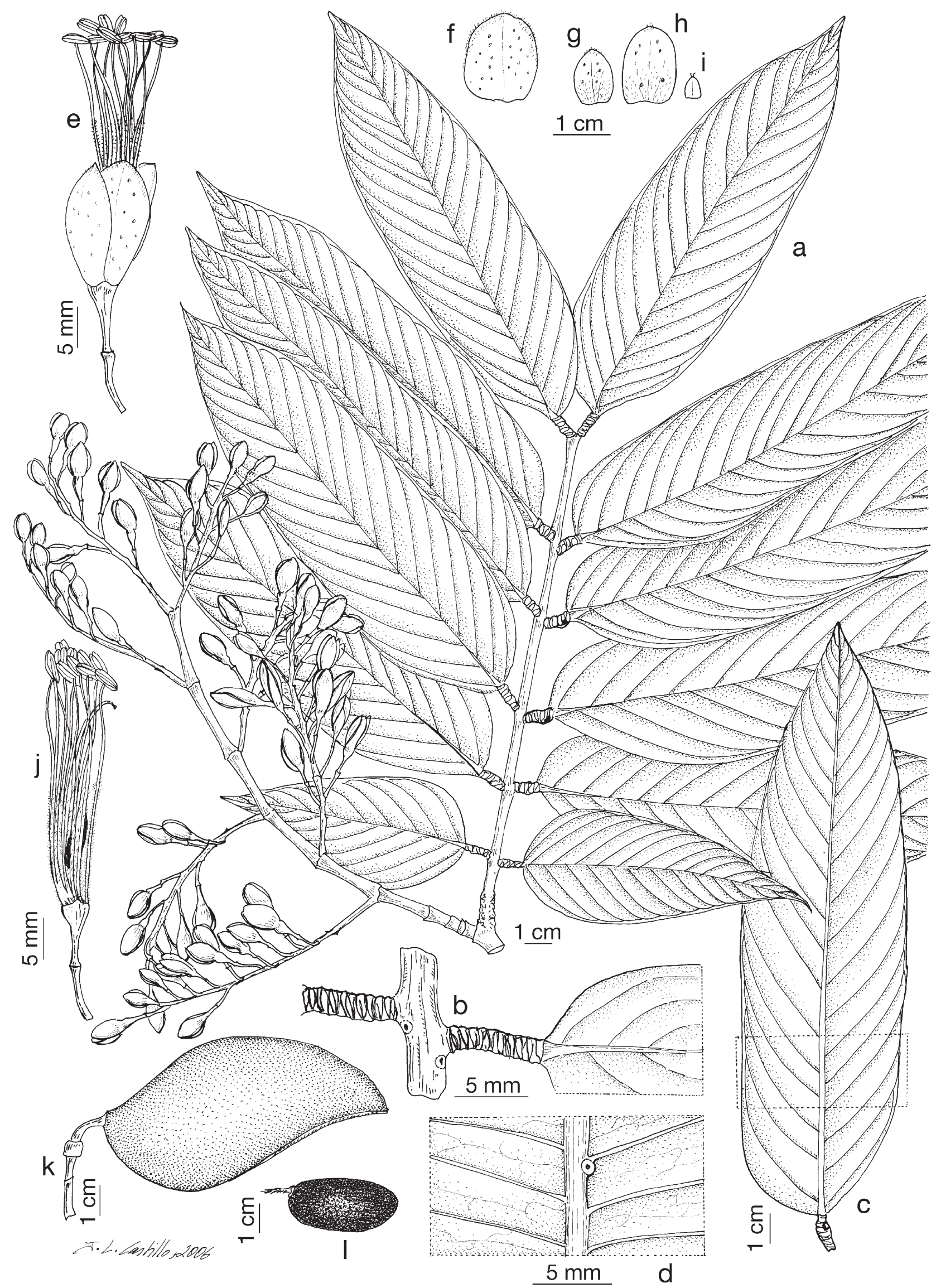

Fig. 6. Daniellia klainei. a. Twig with leaves and inflorescence. b. Insertion of basal pair of leaflets. c. Leaflet, adaxial surface. d. Leaflet gland, abaxial surface. e. Flower. f. Sepal seen from exterior. g. Adaxial petal seen from exterior. h. Lateral petal seen from exterior. i. Abaxial petal seen from exterior. j. Flower without perianth. k. Pod. 1. Seed. [based on: a-b, e-j, Le Testu 1784 (LISC); c, d, k, 1 Breteler et al. 15223 (WAG-91717 and WAG-91718)]. 


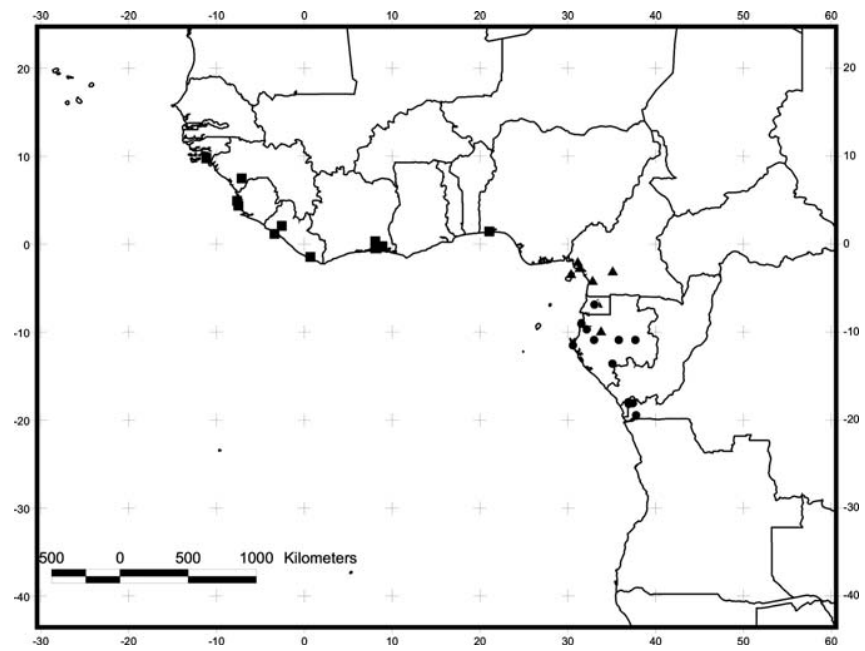

FIG. 7. Distribution of Daniellia klainei (circles), D. oblonga (triangles) and D. thurifera (squares).

sunken glands at the point of insertion of the basal pair of leaflets; petiolules 3-8 $\mathrm{mm}$ long, rachis $17-20 \mathrm{~cm}$ long, terete and shallowly channeled basally becoming terete distally, glabrous, with a pair of glands at the point of insertion of each pair of leaflets, terminating in a small scale $0.5 \mathrm{~mm}$ long, with few short hairs; leaflets subopposite basally, opposite distally, coriaceous, with 10-16 pairs of main lateral veins, translucent gland dots dense, completely glabrous on both faces, small crateriform gland present on the lower surface on the narrower side of the lamina, 3-10 $\mathrm{mm}$ from the base, midrib prominent on the abaxial face, terete, shallowly channeled basally, with a small crest distally; basal leaflet ca. $7 \times 2.7 \mathrm{~cm}$, lanceolate, apex acuminate, acumen $9 \mathrm{~mm}$ long, base rounded and asymmetric; apical leaflet ca. $10 \times 3-4 \mathrm{~cm}$, oblong-lanceolate, apex acuminate, acumen $7.5 \mathrm{~mm}$ long, base cuneate, asymmetric; largest leaflet 11-15(-17) × 4-6 cm, oblong, apex acuminate, acumen $4-8 \mathrm{~mm}$ long, base rounded and asymmetric. Inflorescence a compound raceme, ca. $11 \mathrm{~cm}$ long, peduncle ca. $5 \mathrm{~mm}$ long, rachis slightly pubescent with 7 lateral branches, each ca. $5 \mathrm{~cm}$ long and 14-flowered (immature inflorescence data); bracts ca. $6 \times 4 \mathrm{~mm}$, caducous, obovate, slightly pubescent on the margins and at the apex, inner face slightly pubescent; pedicel 10-17 mm long, slightly twisted at base, glabrous or glabrescent, accrescent in fruit; bracteoles caducous, not seen, inserted at the midpoint of the pedicel. Receptacle 3-6 × 3-6 mm, ciliate within; pedicel plus receptacle 15-22 mm long; flower bud 7-9 mm wide. Flowers pale blue. Sepals 4, 12-22 × 5-9 mm, oblong, with a ciliate margin and a tuft of hairs at the apex, gland dots present on external surface. Petals 5; adaxial petal 10-15 × 7-9 mm, oblong, conduplicate, pubescent on both surfaces, with a few gland dots on the external face; lateral petals 11-20 × 8-15 mm, oblong, velvety within, pubescent at the apex and base and with a few gland dots on the external face; abaxial petals 1.4-2 × 1.1-1.4 $\mathrm{mm}$, triangular, glabrous. Stamens 10 , filaments $27-53 \mathrm{~mm}$ long, 9 united for 3-5 mm, pubescent at least on the lower two-thirds; anthers 1.8-3.5 mm long. Ovary 5-8 mm long, oblong-rhombic, glabrous, more or less smooth, stipe 1-4 $\mathrm{mm}$ long, glabrous or with a few hairs. Pod 7-9 $\times 4.5-5 \mathrm{~cm}$, oblong-round, glabrous, stipe ca. $13 \mathrm{~mm}$ long, pedicel $23 \mathrm{~mm}$ long. Seeds 29-34 × 15-18 × 2-3 mm, oblong, smooth, garnet; funicle ca. $18 \mathrm{~mm}$ long. Figure 8.
Phenology_Flowering is recorded from December to April; fruiting from January to April.

Distribution and Habitat-Known from Cameroon, Equatorial Guinea and Gabon; in forest; 80-700 m. Figure 7.

Vernacular Names-Equatorial Guinea: Nsu (Fang), Foro (Fang). Cameroon: Ingou, Nsou.

Uses-Used for building boats and canoes and historically for railway-sleepers (Burkill 1995).

Specimens Examined-CAMEROON: Nloke, K. Hêndui 1604 (P); Bakundu Foe (Bakundu F. R.), $4^{\circ} 28^{\prime}$ N, $9^{\circ} 13^{\prime}$ E, Keay s. n. (K); près de Bella (45 km NE de Kribi), $3^{\circ} 15^{\prime} \mathrm{N}, 10^{\circ} 12^{\prime} \mathrm{E}$, Letouzey 4152 (P); $\mathrm{km} 28$ de la route Kribi-Lolodorf, Letouzey SRFK 1266 (P); Yaoundé (Jaúnde), 352' N, 1131' E, Mildbraed 7772 (K), 8031 (K); Likomba Pflanzung, 15-35 km NE von Victoria, $4^{\circ} 5^{\prime} \mathrm{N}, 9^{\circ} 20^{\prime} \mathrm{E}$, Mildbraed 10759 (A, K).

EQUATORIAL GUINEA: P. N. Monte Alén, $1^{\circ} 36^{\prime}$ N, $10^{\circ} 4^{\prime} \mathrm{E}$, Senterre, Obiang \& Ngomo 2214 (BRLU).

GABON: 5-30 km NNW of Ndjolé, $0^{\circ} 5^{\prime} \mathrm{S}, 10^{\circ} 45^{\prime} \mathrm{E}$, Breteler et al. 11046 (WAG).

Discussion-Daniellia oblonga is one of the poorest known species. Specimens seen from Cameroon, Equatorial Guinea, and Gabon are few and incomplete. It may be possible to improve the description and species delimitation if more fertile material becomes available.

This species is closely related to Daniellia ogea, but differs in having a glabrous ovary compared to the densely villous to pubescent ovary of D. ogea. The sepals are glabrous, with a ciliate margin and a tuft of hairs at the apex in D. oblonga, whereas in D. ogea the sepals are densely pubescent (Table 1). Finally, a ring of hairs is present around the glands at the point of insertion of each pair of leaflets in D. ogea but absent D. oblonga.

Daniellia oblonga may be easily distinguished from other members of Daniellia subgen. Daniellia by its glabrous or glabrescent petioles, rachis and leaflets. These characters are only shared with $D$. thurifera from which $D$. oblonga may be distinguished by the presence of glands at the insertion point of each pair of leaflets; $D$. thurifera has glands present only at the insertion of the basal pair of leaflets (rarely between the second pair). Furthermore, in D. oblonga the inflorescence rachis is slightly pubescent, but glabrous in D. thurifera.

When Oliver (1871, p. 301) described Daniellia oblonga he cited: "Upper Guinea. Fernando Po, Barter!" but did not indicate a collector's number. Although the "Flora of Tropical Africa" was based principally on material deposited in the Kew herbarium, the identity of the holotype was not clear. Léonard (1950, p. 99) stated that the type material of this species was "Fernando Po: Barter 2074 (typus D. oblonga, Herb. Kew, folioles Mus. Paris)" and selected as lectotype Barter 2074 (K; isolectotype, P).

5. Daniellia ogea (Harms) Rolfe ex Holland, Bull. Misc. Inform. Kew, Addit. Ser. 9: 268. 1911. Cyanothyrsus ogea Harms, Bot. Jahrb. Syst. 26: 270-271. 1899.-TYPE: NIGERIA. Lagos, 1895, Millen 191 [lectotype: designated by Léonard 1950: 104, K!; isolectotype: BM! (only a leaflet)].

Daniellia caudata Craib ex Holland, Bull. Misc. Inform. Kew, Addit. Ser. 9: 268. 1911.-TYPE: NIGERIA. Central Province, Agogidigbo, 11 Dec. 1907, Unwin 179 (lectotype: designated by Léonard 1950: 98, K!).

Daniellia fosteri Craib ex Holland, Bull. Misc. Inform. Kew, Addit. Ser. 9: 268. 1911.-TYPE: NIGERIA. Mamu Reserve, 1906, Foster 156 (lectotype: designated by Léonard 1950: 108, K!).

Daniellia punchii Craib ex Holland, Bull. Misc. Inform. Kew, Addit. Ser. 9: 268. 1911.—TYPE: NIGERIA. Lagos, Ibadan 


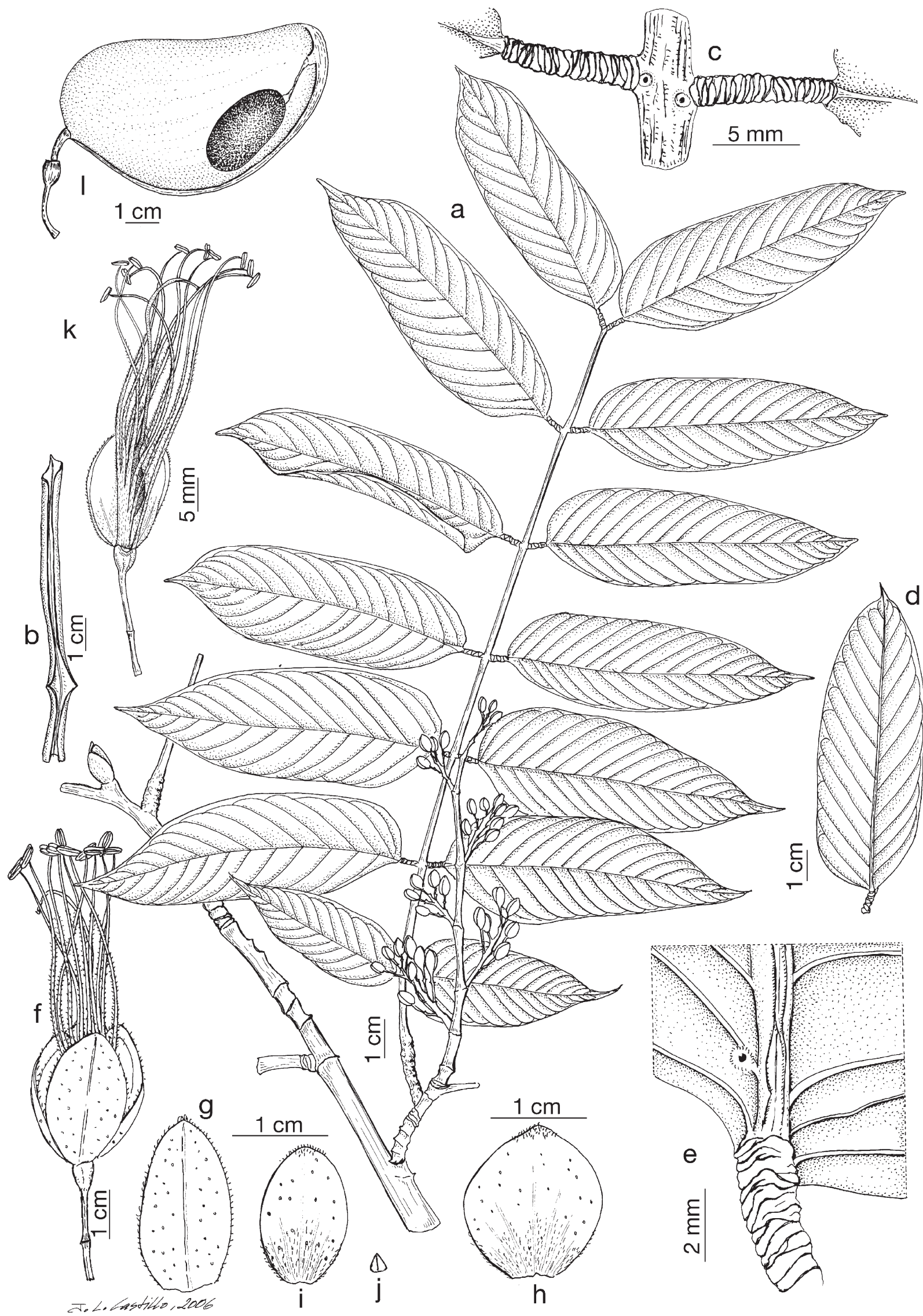

FIG. 8. Daniellia oblonga. a. Twig with leaves and inflorescence. b. Stipule. c. Insertion of basal pair of leaflets. c. Leaflet, adaxial surface. e. Leaflet gland, abaxial surface. f. Flower. g. Sepal seen from exterior. h. Lateral petal seen from exterior. i. Adaxial petal seen from exterior. j. Abaxial petal seen from exterior. k. Flower without perianth. 1. Pod with seed [based on: a, c, d, e, Mildbraed 10759 (A); b, g-k, Breteler et al. 11046 (WAG-110756); f, Barter 2074 (K); 1, Senterre et al. 2214 (BRLU)]. 
Forest Reserve, 25 Nov. 1900, Punch 115 (lectotype: designated by Léonard 1950: 102, K!; isolectotype: E!).

Daniellia similis Craib ex Holland, Bull. Misc. Inform. Kew, Addit. Ser. 9: 268. 1911.—TYPE: GOLD COAST. without locality, 27 March 1909, Dudgeon 5 (lectotype here designated: $\mathrm{K} !)$.

Daniellia thurifera Benn. var. chevalieri J. Léonard, Bull. Jard. Bot. État Bruxelles 19: 407. 1949.-TYPE: SENEGAL. Casamance, Koulaye-Kouraye, Chevalier 2969 (holotype: P!; isotypes: BR!, G!, K!).

Tree ca. $40 \mathrm{~m}$ tall and ca. $125 \mathrm{~cm}$ dbh. Twigs and branches glabrescent, short white hairs on young parts, bud-scale scars patent, more densely so in the inflorescence branches. Leaves 23-39 × 13-19 cm, 5-9-jugate, largest leaflet situated at approximately the midpoint of the leaf; stipules only seen on young twigs, (5-)6-13 × 2.5-4(-6) mm, lanceolate, revolute, slightly pubescent on both surfaces; accrescent up to 80-85 mm long, caducous; petiole 20-38(-47) mm long, terete, shallowly channeled, glabrous, with a pair of small rounded sunken glands with a few marginal hairs at the point of insertion of the basal pair of leaflets; petiolules 3-9 $\mathrm{mm}$ long; rachis (11-)15-24(-27) cm long, subterete and shallowly channeled at the base becoming quadrangular distally, glabrous, with a pair of glands surrounded by a margin of hairs at the point of insertion of each pair of leaflets, terminating in a small scale 0.5-3 mm long, glabrous or with a few short hairs; leaflets: basal pair subopposite, otherwise all opposite, coriaceous to papyraceous, variable depending on the age of the leaflets, minutely mucronate, with 8-16 pairs of main lateral veins, translucent gland dots dense, usually glabrous on both faces, rarely sparsely hairy at the base of the midrib on the abaxial face, crateriform glands present on the lower surface, with one or two small glands, one always present on the midrib near the petiolule, on the narrower lamina side, another sometimes present on a lateral vein on the broader lamina side, midrib prominent on the abaxial face, terete, shallowly channeled basally with a small crest distally; basal leaflet 5-9 $\times 1.5-3.5 \mathrm{~cm}$, elliptic-lanceolate, apex acuminate, acumen ca. $2 \mathrm{~mm}$ long, base rounded and asymmetric; apical leaflet 7-12 $\times(2-) 2.5-4 \mathrm{~cm}$, lanceolate, apex acuminate, acumen 3-8 mm long, base cuneate, asymmetric; largest leaflet 7-11(-15) $\times$ (2.5-)3-4 cm, oblong-lanceolate, apex acuminate, acumen 3-11 $\mathrm{mm}$ long, base rounded and asymmetric. Inflorescence a compound or double compound raceme, (7-)15-20(-22) cm long, peduncle (3-)6-8(-10) mm long, with 5-12 lateral branches each (4-)5-6.5(-9) cm long and 10-25-flowered; rachis tomentose; bracts ca. $7 \times 3 \mathrm{~mm}$, caducous, oblong, pubescent, inner face slightly pubescent; pedicel 9-15(-17) mm long, slightly twisted at base, velvety pubescent, accrescent in fruit; bracteoles 5-8 $\times 3-4 \mathrm{~mm}$, caducous, obovate, pubescent on both faces, inserted at the midpoint of the pedicel. Receptacle $4-6 \times$ 2-5 mm, ciliate within; pedicel plus receptacle 13-20(-23) $\mathrm{mm}$ long; flower bud 4-6(-8) mm wide. Flowers blue to dark lilac or violet. Sepals 4, 10-13(-19) × 5-9 mm wide, oblong, pubescent on external face, except in imbricate areas zones which are glabrous and have small gland dots. Petals 5; adaxial petal, 6-10 × 3-6(-8) mm, oblong-elliptic, slightly conduplicate, pubescent at the base and apex of both surfaces, smooth or with few gland dots; lateral petals $8-11(-15) \times(4-) 6-9(-10)$ $\mathrm{mm}$, oblong, rounded, velvety within, pubescent on the external face and margins, with a few gland dots on external face; abaxial petals $1-2(-3) \times 0.5-1(-1.5) \mathrm{mm}$, oblong-lanceolate, glabrous or with few hairs at the apex. Stamens 10, filaments (17-)22-26(-32) mm long, 9 united at the base for 2-6(-7.5) $\mathrm{mm}$, pubescent at least on the lower two-thirds; anthers (1.6-) 1.9-2.4(-3.1) mm long. Ovary (5-)6-7 mm long, oblong-rhombic, densely villous, surface slightly grainy, stipe $1-4(-5) \mathrm{mm}$ long, densely pubescent; style 14-21(-28) mm long, slightly pubescent in the base; stigma grainy. Pod 6-7(-9) × 2.5-3.5(-5) $\mathrm{cm}$, one margin straight, the other \pm round, densely pubescent mainly in the margin, stipe $6-9(-12) \mathrm{mm}$ long, pedicel 24-31(-36) mm long. Seeds 28-31 × 18-21 × 2.5-3 mm, oblong, smooth, dark brown; funicle 15-16 mm long. Figure 9.

Phenology-Flowering is recorded from September to May, fruiting from November to March. Hambler 115 (K!) reported that the flowers were caducous and the leaves appeared only as the flowers fell.

Distribution and Habitat-West and west central Africa; semideciduous forest, high forest and near water sources; 10-800 m. Figure 10.

Vernacular Names-Benin: Ijuga (Dahomeés). Ivory Coast: Faro (French). Senegal: Santaforo.

Uses-The gum is used in cosmetic, medicinal, magic, and medico-magical treatments (Burkill 1995).

Representative Specimens Examined-BENIN: Zou, Ouinhi, Dasso Champ, 7 $1^{\prime} \mathrm{N}, 2^{\circ} 28^{\prime}$ E, Adjakidjè, Agbani \& Yédomonhan 3985 (WAG); Dahomey, Porto Novo, 6²9' N, 2³7' E, Noury 25603 (P).

CAMEROON: Ndiki, Jacques-Félix 2536 (MO, P, WAG).

EQUATORIAL GUINEA: Bioko Norte, Malabo-Sampaka, km 4-5, $3^{\circ} 43^{\prime}$ N, $8^{\circ} 45^{\prime}$ E, Carvalho 3789 (AAU, B, BR, FI-photo, H, K, MA, P, U, UPS); Bioko, 3ำ1' N, $8^{\circ} 47^{\prime} \mathrm{E}$, Mann 166 (K).

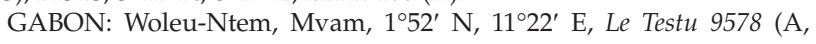
B, BM, BR, K, LISC, P); Estuaire, Crystal Mountains, $0^{\circ} 40^{\prime} \mathrm{N}, 10^{\circ} 32^{\prime} \mathrm{E}$, Nguema Miyono 1799 (WAG).

GHANA: Gold Coast, 521' N, 055’ W, Ayon 2644 (A); Gold Coast, Mpraeso, 63' N, 044' W, Beveridge 3210 (BM); Gold Coast, Imperial Institute s. n. (K); Ashanti, Sekyere, Bobiri Forest Reserve, $6^{\circ} 38^{\prime} \mathrm{N}, 1^{\circ} 17^{\prime} \mathrm{W}$, Kisseadoo 91 (NY).

GUINEA BISSAU: Teixeira Pinto, Cacheu, praia Varela, $12^{\circ} 17^{\prime} \mathrm{N}$, $16^{\circ} 35^{\prime} \mathrm{W}, \mathrm{D}^{\prime}$ Orey 175 (K, LISC).

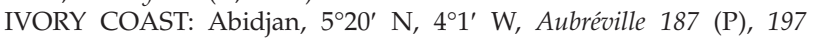

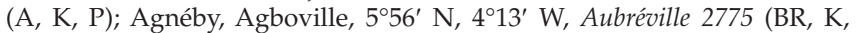
P); Abouabou, 517' N, 354' W, J.-G. Adam 6502 (US); without locality, Aubréville 1064 (P).

LIBERIA: Nimba, New Bapa, 7³4' N, 8³3' W, Adames 561 (K, UPS); Western Province, Boropo, Kondessu, Baldwin 10675 (K); Gbanka (Banga), $7^{\circ} 16^{\prime} \mathrm{N}, 10^{\circ} 3^{\prime} \mathrm{W}$, Linder 1233 (K); Zle (Tiatown), 10 miles E of Tapeta, $6^{\circ} 15^{\prime} \mathrm{N}, 8^{\circ} 28^{\prime} \mathrm{W}$, Voorhoeve 517 (WAG); Bong, Loma National Forest near Basiweng, $7^{\circ} 15^{\prime} \mathrm{N}, 9^{\circ} 30^{\prime} \mathrm{W}$, Voorhoeve 721 (WAG).

NIGERIA: Benin, Okomu Forest Reserve, $6^{\circ} 20^{\prime} \mathrm{N}, 5^{\circ} 15^{\prime} \mathrm{E}$, Brenan et al. 8817 (BM, BR, COI, K, P); Abakaliki, Obubra, Ukpon River Forest Reserve, $6^{\circ} 20^{\prime} \mathrm{N}, 8^{\circ} 6^{\prime}$ E, Eze s. n. (K); Nigerian College A. S. T., Ibadan, Hambler 115 (K); Lagos, $6^{\circ} 27^{\prime} \mathrm{N}, 3^{\circ} 23^{\prime} \mathrm{E}$, Inspector of Forest s. $n$. (BR); Ikom, Iso Bendiga, Bendiga Afi, $6^{\circ} 7^{\prime} \mathrm{N}, 8^{\circ} 42^{\prime}$ E, Keay s. $n$. (K); West Province, H. Thompson 18 (K); without locality, Kenedy 328 (BM, K), 329 (A), 330 (A, BM, K).

SENEGAL: région Bignona, forêt de Tanguème, Berhaut 5962 (P); Region de Bignona, foret des Kalounayes, Tèndimann, $12^{\circ} 48^{\prime} \mathrm{N}, 16^{\circ} 6^{\prime} \mathrm{W}$, Berhaut 6748 (BR); Kaéme (Kaém), 12³1' N, 16³3' W, Miege \& Doumbia 854 (G); Basse Casamance, Boutolatte, $12^{\circ} 49^{\prime} \mathrm{N}, 1^{\circ} 13^{\prime} \mathrm{W}$, Rambault s. n. (P); Yantanfro au Bouyinck, Bignona, Casamance, Servicie Forestier $d u$ Senegal $45(\mathrm{P})$.

SIERRA LEONE: Seli crossing, Kamadugu Chiefdom, Glanville 484 (K); Loma, $9^{\circ} 45^{\prime} \mathrm{N}, 12^{\circ} 2^{\prime} \mathrm{W}$, Jaeger 8920 (P); Gola forest, Unwin \& Smythe $45(\mathrm{~K})$.

TOGO: Amoutchou-Tal bei Oga, $7^{\circ} 23^{\prime}$ N, $1^{\circ} 11^{\prime}$ E, Ern 2805 (B); Tomégbé bei Bandou, Ern 2828 (B).

Discussion-Daniellia ogea is widely dispersed in west and west central Africa and is the most problematic species to delimit, as a result of a considerable variation in leaflet shape, size and texture, and of particular note is the difference between young and mature leaflets.

Daniellia ogea can be distinguished from other species by the combination of usually glabrous leaflets, a ring of hairs 


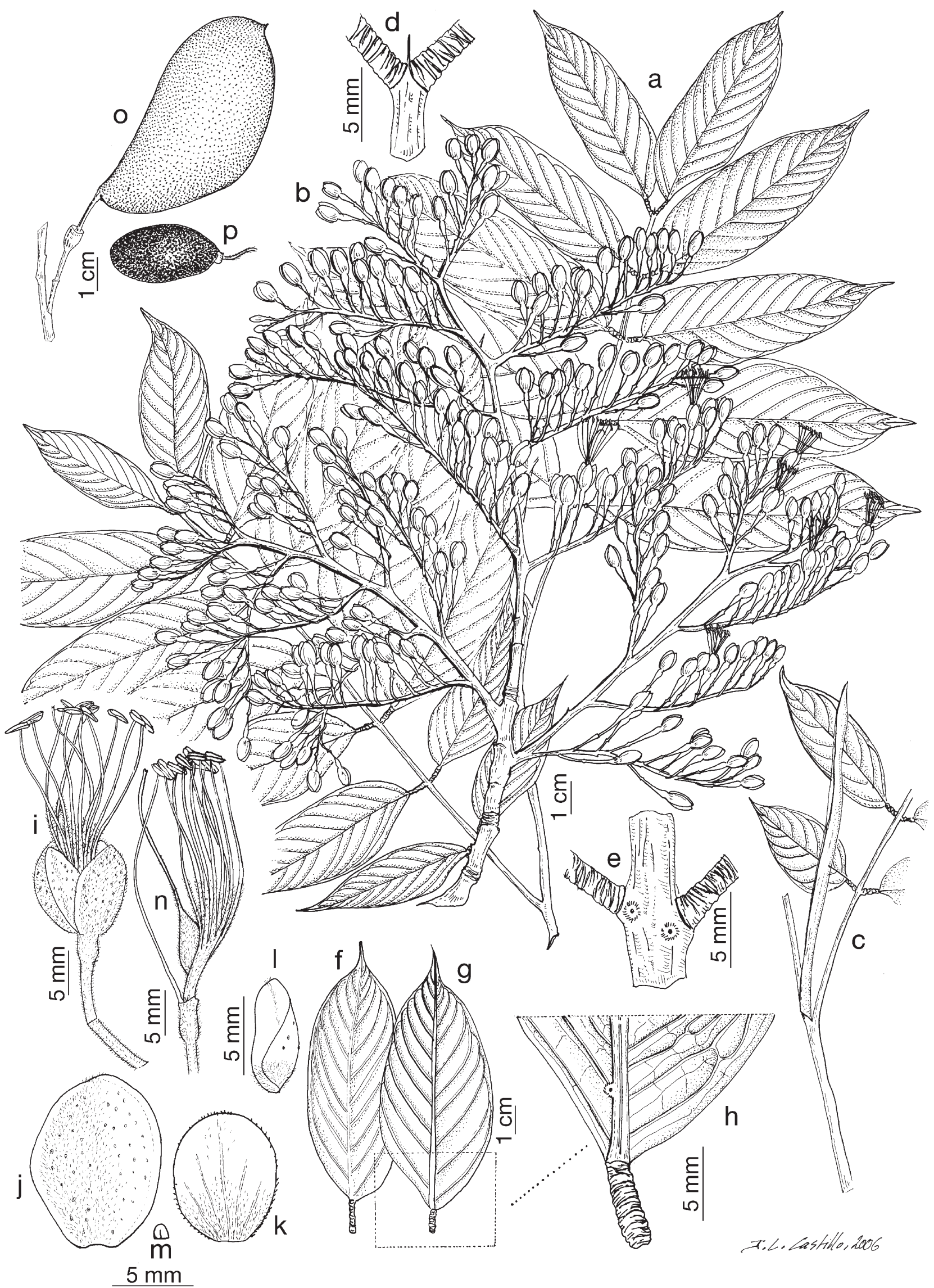

Fig. 9. Daniellia ogea. a. Twig with leaves. b. Inflorescence. c. Stipule. d. Apical pair of leaflets insertion. e. Insertion of basal pair of leaflets. f. Leaflet (immature), adaxial surface. g. Leaflet, adaxial surface. h. Leaflet gland, abaxial surface. i. Flower. j. Sepal seen from exterior. k. Lateral petal seen from exterior. 1. Adaxial petal seen from lateral side. m. Abaxial petal seen from exterior. n. Flower without perianth. o. Pod. p. Seed. [Based on: a-b, d, e, g, o-p; Carvalho 3789 (MA-512442); b, i-n, Voorhoeve 735 (WAG-18392); c, Unwin \& Smythe 109 (K); f, h, Jacques-Félix 2536 (WAG-154421)]. 


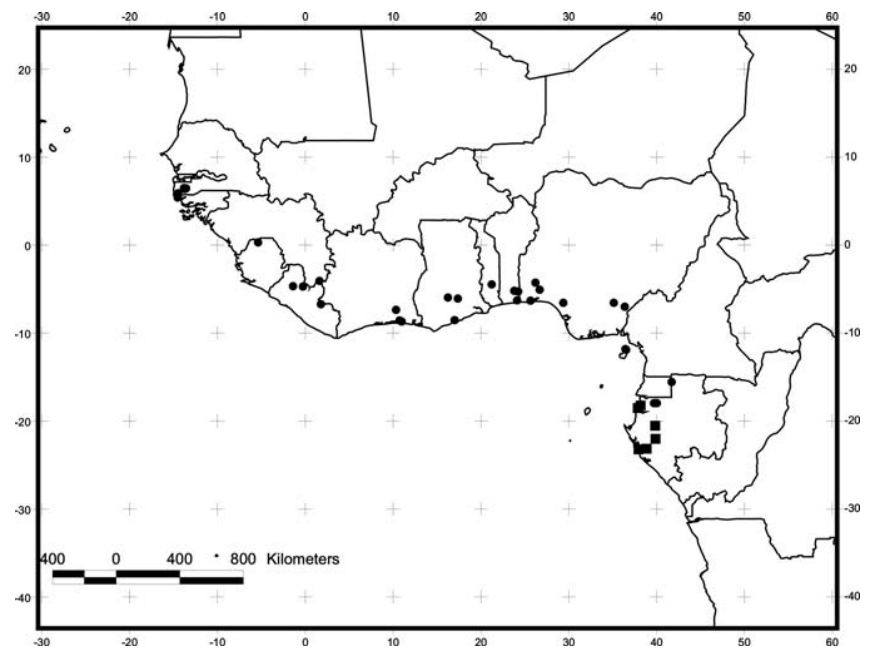

FIG. 10. Distribution of Daniellia ogea (circles) and D. soyauxii (squares).

surrounding the glands at the insertion of each pair of leaflets, flowers with densely pubescent sepals and a densely villous ovary (Table 1). This character combination is consistent with most specimens seen, but a few exceptions e.g. Carvalho 3789 and Aubréville 1064 were pubescent on the abaxial face of the midrib which might lead to confusion with Daniellia. pilosa. However, D. pilosa can be distinguished from $D$. ogea by the absence of glands at leaflet insertion, smaller flowers [e.g. sepals 10-13(-19) $\mathrm{mm}$ long in D. ogea as compared to 8-12(-13) in D. pilosa], and larger inflorescences, (7-)15$20(-22) \mathrm{cm}$ in D. ogea as compared to $10-20(-150) \mathrm{cm}$ in D. pilosa. Daniellia ogea is also close related to D. soyauxii, but the latter can be distinguished by the absence of glands at the point of insertion of the leaflets in conjunction with glabrous sepals (save for a few hairs along the margins and at the apex; Table 1).

Daniellia ogea shows considerable variation in leaflet shape and size depending on the age of the tree. Some collectors reported that the species was flowering when leafless (e.g. Voorhoeve 721). Historically, confusion over the delimitation of this species lead to the description of D. fosteri and D. similis, which are treated here as synonyms of D. ogea.

Daniellia caudata and D. punchii were based on Unwin 179 (K) and Punch 115 (K, E), respectively, but Keay (1954, p. 491) reported correctly that both were mixed collections. Unwin 179 is a specimen made up of the flowers and fruits of D. ogea and the leaves of Clitandra barteri Stapf (Apocynaceae), and Punch 115 consists of flowers from D. ogea and leaves from a Crudia sp. (Leguminosae-Caesalpinioideae). Keay (1954, p. 491) also noted that Chevalier 2969 (holotype of D. thurifera var. chevalieri) consists of a mixed collection of flowers from D. ogea and leaves and flowers from $D$. oliveri.

In the protologues of Daniellia caudata, D. fosteri, D. ogea, $D$. punchii and D. similis, the authors did not designate types, but later when Léonard (1950, pp. 98, 102, 104, 108) studied these species, he referred to type material, thus lectotypifying the names.

6. Daniellia pilosa (J. Léonard) Estrella, Ann. Bot. Fennici 44: 149. 2007. Daniellia soyauxii var. pilosa J. Léonard, Bull. Jard. Bot. État Bruxelles 19: 407. 1949.-TYPE: GABON. OgoouéLolo, región de Lastoursville, Nzambi, 29 August 1930, Le Testu 8292 (holotype: P!; isotypes: BM!, BR!, LISC!, MO!).
Tree $40 \mathrm{~m}$ tall and ca. $1.5 \mathrm{~m}$ dbh, with a cylindrical bole and horizontal scars on the bark. Twigs and branches \pm glabrescent (short white hairs on youngest parts), bud-scales scars clearly visible on the inflorescence branches, less so on the vegetative branches. Leaves 17-24 × 9-13 cm, 5-10-jugate, largest leaflet situated at about the midpoint of the leaf; stipules only seen on young twigs, $4-10(-12) \times(1-) 1.5-3 \mathrm{~mm}$, lanceolate, revolute, silky pubescent mainly on the margins and at the apex; petiole 7-16(-28) mm long, subterete, pubescent; petiolules 1.7-5 mm long; rachis (9-)13-16(-24) cm long, subterete and shallowly channeled at least at the base, sometimes along its entire length, becoming quadrangular distally, glabrous to glabrescent on the adaxial face, silky pubescent on abaxial face, without glands at the point of insertion of the leaflets, terminating in a small scale $0.5-1 \mathrm{~mm}$ long, slightly pubescent; leaflets subopposite basally, opposite distally, coriaceous, minutely mucronate, with 9-16 pairs of main lateral veins, translucent gland dots dense, adaxial face glabrous, abaxial face glabrous except along the midrib which is usually densely pubescent, small crateriform gland present near the petiolule, on the narrower side of the lamina, midrib prominent on the abaxial face, channeled; basal leaflet 3.6-5.2 $\times$ $1.5-2 \mathrm{~cm}$, ovate-lanceolate, apex acuminate, acumen 1.5-2.2 $\mathrm{mm}$ long, base rounded and asymmetric; apical leaflet 5-6.5 $\times$ $1.5-2.5 \mathrm{~cm}$, lanceolate, apex acuminate, acumen $2.6-4.6 \mathrm{~mm}$ long, base cuneate; largest leaflet 5-7(-11) × (1.5-)2-2.5(-4) $\mathrm{cm}$, oblong-lanceolate, apex acuminate, acumen $2-5(-11) \mathrm{mm}$ long, base rounded and asymmetric. Inflorescence a double compound raceme, 10-20(-150) cm long, peduncle (4-)7-9 $\mathrm{mm}$ long, with 9-13 lateral branches, each 2.5-7 cm long and 9-21-flowered; rachis long velvety; bracts caducous; pedicel 7-11 mm long, slightly twisted at base, velvety pubescent, accrescent in fruit; bracteoles caducous, inserted at the midpoint of the pedicel. Receptacle (1.5-)2-3(-3.5) × 1-3 mm, margin ciliate within; pedicel plus receptacle 10-14 mm long; flower bud $4-5.5 \mathrm{~mm}$ wide. Flowers blue to violet. Sepals $4,8-12(-13) \times 5-7 \mathrm{~mm}$, elliptic, densely velvety pubescent, with gland dots on external surface. Petals 5; adaxial petal, (4-)5-8 × 2.5-5 mm, oblong-ovate, pubescent within, pubescent externally at the base and apex, with a few gland dots on the external face; lateral petals 7-10 × 6-9 mm, oblong-ovate, margins ciliate, external surface glabrescent, internal surface villous; abaxial petals $1.5-2.5(-3) \times 0.5-1 \mathrm{~mm}$, lanceolate, glabrous or almost so. Stamens 10, filaments (13-)16-25(-28) mm long, 9 united at the base for $0.4-1.1 \mathrm{~mm}$, pubescent at least on the lower two-thirds; anthers 2.2-3 mm long. Ovary 3.5-6 $\mathrm{mm}$ long, oblong, densely villous, surface slightly grainy due to the presence of gland dots, stipe $2-3 \mathrm{~mm}$ long, villous; style 9-24 mm long, villous in the basal half; stigma rounded. Pod $4.5-7 \times 2.5-3.5 \mathrm{~cm}$, elliptic, asymmetric, densely pubescent mainly along the margin, stipe (3-)5.5-7 $\mathrm{mm}$ long, pedicel 7-12 mm long. Seeds $27 \times 16 \times 3 \mathrm{~mm}$, elliptic, smooth, dark brown; funicle not seen. Figure 11.

Phenology —Flowering is recorded from March to September; fruiting from October to February.

Distribution and Habitat-Gabon, Congo (Brazzaville), and Congo (Kinshasa); in mountain primary forest; 20-600 m. Figure 12.

Vernacular Names-Gabon: Egnongnouma (Pahouin), Lonlaviol (Fang).

Uses-None recorded.

Representative Specimens Examined-CONGO (Brazzaville): Odzala N. P. (Mboko), $0^{\circ} 53^{\prime} \mathrm{N}, 14^{\circ} 50^{\prime}$ E, Dowsett-Lemaire 1600 (BR); Kouilou, Sargos $10(\mathrm{P})$. 


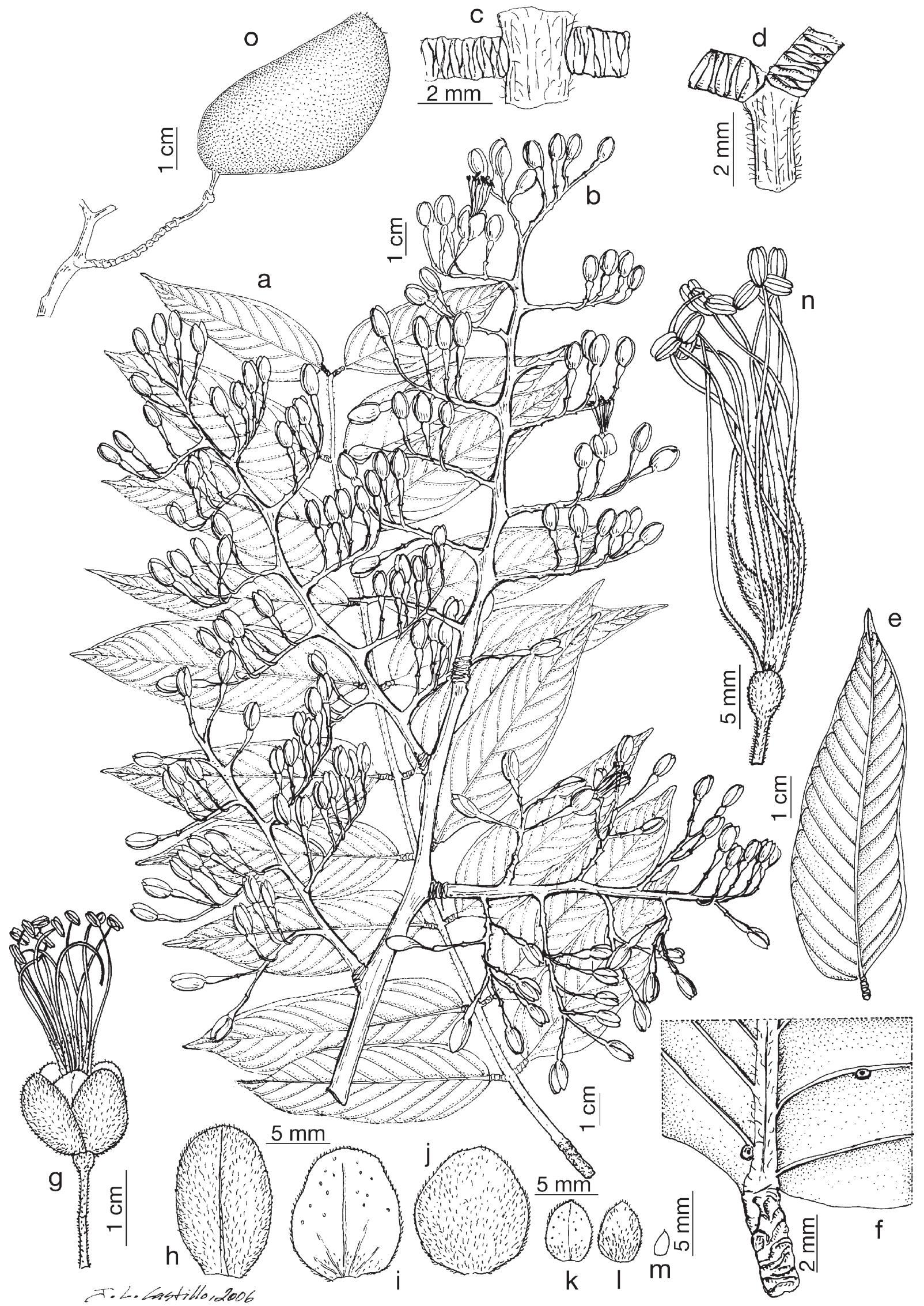

Fig. 11. Daniellia pilosa. a. Leaves. b. Inflorescence. c. Insertion of basal pair of leaflets. d. Apical pair of leaflets insertion. e. Leaflet, adaxial surface. f. Leaflet glands, abaxial surface. g. Flower. h. Sepal seen from exterior. i. Lateral petal seen from exterior. j. Lateral petal seen from inside. k. Adaxial petal seen from exterior. l. Adaxial petal seen from inside. m. Abaxial petal seen from exterior. n. Flower without perianth. o. Pod. [based on: a-n, Wieringa \& van de Poll 1462 (WAG-110750); o, Wilks \& Dibata 2703 (WAG-110752)]. 


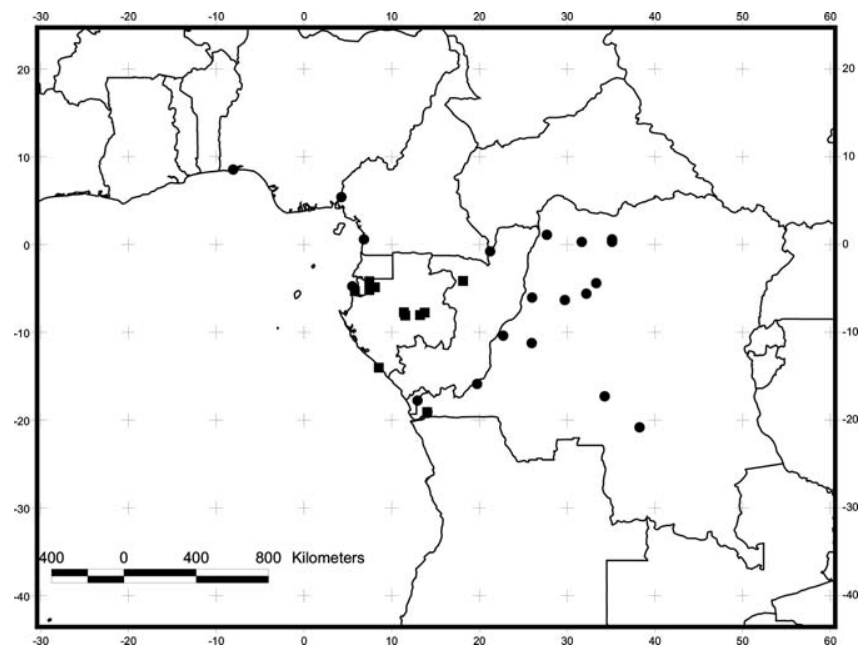

FIG. 12. Distribution of Daniellia pilosa (squares) and D. pynaertii (circles).

CONGO (Kinshasa): Ineac-Luki, territoire Lukula, Bloc H 55, Limite Nord, Hombert 165, 170, 176, 178, 194, 199 and 213 (BR); Ineac-Luki, Territoire Lukula, Bloc H.50, Hombert 428 (BR); Ineac-Luki, Mayumbe, $5^{\circ} 38^{\prime} \mathrm{S}, 13^{\circ} 3^{\prime} \mathrm{E}$, Hombert 481 (BR, MO), 492 (BR), 501 (BR, WAG) and 502 (BR, WAG).

GABON: Environs de Diobomayola, sur l'Orimbo, affluent del'Ogooué, Fleury 26553 (P); Mivanen, env. Libreville, 0²3’ N, 9²7' E, Fleury 33707 (P); Station Ikoy, Gauchotte 1712 (P), 1715 (P); Ogooué-Lolo, forêt des Abeilles, $0^{\circ} 40^{\prime}$ S, 115' E, F. Hallé 4610 (WAG); Nyanga, Mayumba (Mayoumba), 3²5' S, 10³9’ E, Le Testu 2062 (BM, BR, LISC, P); Tchibanga, Le Testu 2262 (K); Estuaire, Crystal Mountains, 034' N, 10²7' E, Nguema Miyono 1680 (WAG); Estuaire, Crystal Mountains, $0^{\circ} 52^{\prime} \mathrm{N}, 1^{\circ} 11^{\prime} \mathrm{E}$, Nguema Miyono 1713 (WAG); Estuaire, Crystal Mountains, $0^{\circ} 26^{\prime} \mathrm{N}, 1^{\circ} 11^{\prime} \mathrm{E}$, Nguema Miyono 1996 (WAG); km 18, Saint Aubin 2050 (P); Ogooué-Lolo, 28 km NE of Lastoursville, $0^{\circ} 41^{\prime} \mathrm{S}, 12^{\circ} 56^{\prime} \mathrm{E}$, Wieringa $\mathcal{E}$ van de Poll 1462 (G, WAG); Ogooué-Lolo, Forêt des Abeilles, $13 \mathrm{~km}$ SE of the confluence of GonguéOffoué river, $0^{\circ} 50^{\prime} \mathrm{S}, 1^{\circ} 58^{\prime} \mathrm{E}$, Wilks E Dibata 2703 (MA, UPS, WAG).

Discussion-Daniellia pilosa is restricted to central Africa, and has a double compound, densely pubescent, racemose inflorescence, a character combination shared only with $D$. ogea and D. pynaertii from which it is distinguished by the absence of glands at the point of insertion of the leaflets (the type specimen of $D$. pilosa alone has a pair of glands at the point of insertion of the basal pair of leaflets).

The absence of rachis glands is noteworthy because it is a character shared only with $D$. soyauxii. When first described by Léonard (1950, p. 105), Daniellia pilosa was recognised as a variety of $D$. soyauxii. However, it is possible to distinguish D. pilosa from D. soyauxii (Estrella et al. 2007) based on several morphological characters, $D$. pilosa has a pubescent midrib (glabrous in D. soyauxii) and the sepals of D. pilosa are velvety pubescent (glabrous except for a ciliate margin and an apical tuft of hairs in D. soyauxii). The inflorescence of $D$. pilosa can be very long, reaching $150 \mathrm{~cm}$ in Wieringa $\mathcal{E}$ van de Poll 1462, as compared with $3-10 \mathrm{~cm}$ long in $D$. soyauxii. The number of lateral branches in the inflorescence, 9-13 in $D$. pilosa but only to 5-6 in D. soyauxii also separate these two species (Table 1).

7. Daniellia pynaerti De Wild., Ann. Mus. Congo Belge 5 (3): 193. 1910._TYPE: CONGO. Équateur, Eala, 20 Nov. 1906, Pynaert 679 (lectotype: designated by Léonard 1950: $111, \mathrm{BR} !)$.

Daniellia mortehanii De Wild., Bull. Jard. Bot. État Bruxelles 7: 260. 1920.-TYPE: CONGO. Équateur, Forestier Central, Dundusana, Dec. 1913, Mortehan 931 (lectotype designated here: only flowers, BR!).
Daniellia pubescens Hutch. \& Dalziel, Bull. Misc. Inform. Kew 9: 382. 1928.-TYPE: NIGERIA. Southern Province, Lagos Colony, May 1883, Moloney s. n. (lectotype: designated by Léonard 1950: 112, K!).

Daniellia ealaensis Baker f., Rev. Zool. Bot. Africaines 21: 305. 1932. (sphalm. calaenois)_TYPE: CONGO. Équateur, Forestier Central, Eala, 13 April 1931, Corbisier Baland 1032 (holotype: BR!; isotype: BM!).

Tree ca. $40 \mathrm{~m}$ tall and ca. $2.4 \mathrm{~m}$ dbh. Twigs and branches glabrescent with short white hairs on young parts, bud-scale scars clearly visible on the inflorescence branches, less clearly so on the vegetative branches. Leaves (10-)20-28(42) $\times(10-)$ $12-15(-26) \mathrm{cm}, 5-10$-jugate, largest leaflet situated at about the midpoint of the leaf; stipules only seen on young twigs (3-)7$10(-14) \times(1.5-) 2-5 \mathrm{~mm}$, slightly falcate, revolute, pubescent to glabrescent, long hairs on the apex, accrescent 78-99 × 15-19 $\mathrm{mm}$, pubescent within, glabrescent exterior, caducous; petiole 14-30 mm long, subterete, shallowly channeled, pubescent to glabrescent, with a pair of small rounded glands just at the insertion of basal pair leaflets; petiolules (3-)4-6(-8) $\mathrm{mm}$ long; rachis (8-)14-18(-24) cm long, subterete and shallowly channeled at the base, becoming quadrangular distally, villous, with a pair of glands at the insertion of each pair of leaflets surrounded by a tuft of hairs, terminating in a small scale $0.5-2 \mathrm{~mm}$ long, slightly pubescent; leaflets: basal pair subopposite, otherwise opposite, coriaceous to papyraceous, minutely mucronate, with 15-36 pairs of main lateral veins, translucent gland dots sparse, adaxial face glabrous, abaxial face glabrous except on the midrib which is usually densely pubescent, small crateriform gland present on the narrow side of the lamina, 2-8 $\mathrm{mm}$ from the petiolule, midrib prominent on the abaxial face, terete, with a crest along its entire length; basal leaflet 5-9 × 2-3.5(-4) cm, oblong-lanceolate, apex acuminate, acumen 4-9 mm long, base cuneate and asymmetric; apical leaflet $8-10 \times(2-) 2.5-5 \mathrm{~cm}$, oblong-lanceolate, base cuneated, asymmetric, with an acumen (2-)2.5-4 mm long; largest leaflet 6-11(-18) × (1.5-)2.5-5 cm, oblong-lanceolate, base rounded and asymmetric, with an acumen $4-6(-7) \mathrm{mm}$ long. Inflorescence a compound or double compound raceme, 8-13 cm long, peduncle (4-)7-29(-38) mm long, with 4-11 lateral branches, each 4-7 cm long and 11-25-flowered; rachis slightly pubescent; bracts $4.5-7.5 \times 7-8 \mathrm{~mm}$, early caducous, oblong-lanceolate, chaffy pubescent on both surfaces; pedicel 8-13(-14) mm long, slightly twisted at base, glabrescent, accrescent in fruit; bracteoles 7-10 × 4-6 mm, caducous, obovate-elliptic, glabrous except on margin and apex, inserted at the midpoint of the pedicel. Receptacle $2-5 \times(1.5-) 2.5-4 \mathrm{~mm}$, margin ciliate within; pedicel plus receptacle 12-18 mm long; flower bud 4-9 mm wide. Flowers blue to violet. Sepals 4, (11-)13-15(-19) × 8-12(-14) mm, oblong, slightly pubescent on margins and apex, with gland dots on external surface. Petals 5; adaxial petal $8-11 \times 5-8 \mathrm{~mm}$, oblong, velvety at the base and pubescent at the apex, smooth or with few gland dots; lateral petals 10-13 × 6-11 mm, oblong, rounded, velvety within, pubescent at the apex and base of the external face, smooth or with few gland on external face; abaxial petals (1.5-)3-4 × 1-2 mm, oblong-ovate, with few hairs at the apex. Stamens 10, filaments 23-30 mm long, 9 united at the base for $0.5-1 \mathrm{~mm}$, pubescent at least on the lower two-thirds; anthers (1.8-)2.2-3 mm long. Ovary 5-7 mm long, oblong-rhombic, pubescent to glabrescent, grainy, gland dots not present, stipe 2-4 mm long, slightly pubescent; style 16-30 mm long, 
glabrescent. Pod 6-8 $\times 3-4 \mathrm{~cm}$, one margin straight, the other rounded, pubescent to glabrescent mainly near the base, stipe (6-)8-9 mm long, pedicel 22-26 mm long. Seeds 15-29 × 7-16 × 1.2-4 mm, oblong, smooth, dark brown; funicle ca. $9 \mathrm{~mm}$ long. Figure 13.

Phenology-Flowering is recorded from November to June, soon after or before new leaves appear (Thomas 1125); fruiting from August to March.

Distribution and Habitat-Central Africa; 20-670 m. Figure 12.

Vernacular Names-Central African Republic: Mpongopongo. Congo (Kinshasa): Biembié, Bolengu (Lokundu), Eboko, Mondjumbu, Mupaku (Tshiluba).

Uses-Bark used in traditional medicine (Burkill 1995).

Representative Specimens Examined - CAMEROON: Sud, Kribi, Adjap $35 \mathrm{~km}$ östl., $2^{\circ} 57^{\prime} \mathrm{N}, 9^{\circ} 55^{\prime} \mathrm{E}$, Mildbraed 6087 (HBG); Korup reserve, $5^{\circ} 3^{\prime} \mathrm{N}$, $8^{\circ} 48^{\prime} \mathrm{E}, \mathrm{D}$. W. Thomas 1125 (K).

CENTRAL AFRICAN REPUBLIC: Dzanga-Sangha Reserve, Ndakan, $2^{\circ} 22^{\prime} \mathrm{N}, 16^{\circ} 12^{\prime} \mathrm{E}$, Harris \& Fay 938 (MO).

CONGO (Brazzaville): Sous-Préfecture de Fort-Rousset, Kangini, Bouquet $1475(\mathrm{P})$.

CONGO (Kinshasa): Nsele, $4^{\circ} 14^{\prime} \mathrm{S}, 1^{\circ} 33^{\prime} \mathrm{E}$, Callens 368 (BR); Équateur, Eala, $0^{\circ} 4^{\prime} \mathrm{N}, 18^{\circ} 17^{\prime} \mathrm{E}$, Corbisier Baland 779 (BR, K, P, U, WAG); Kakenge, 4 $4^{\circ} 51^{\prime}$

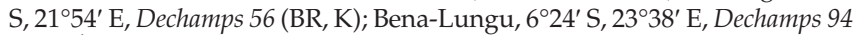
(BR); Équateur, Befale, Likako, $0^{\circ} 15^{\prime} \mathrm{N}, 2^{\circ} 59^{\prime} \mathrm{E}$, Evrard 3065 (BR, K, LISC); Selenge, Flamigni 10258 (BR, K); Équateur, Eala, 04' N, 18 $8^{\circ} 7^{\prime}$ E, Germain 1901 (BR, K); Equatéur, Busira, 04' S, 1955' E, Ghesquière 2686 (A, B, BR, K, P); Bas-Congo, Leopoldville, $5^{\circ} 38^{\prime} \mathrm{S}, 13^{\circ} 4^{\prime}$ E, Gilbert s. n. (BR); Likimi, $2^{\circ} 50^{\prime}$ N, 2045' E, Giorgi 159 (BR); Dundusana, 2 ${ }^{\circ} 50^{\prime}$ N, 22 $2^{\circ} 16^{\prime}$ E, Giorgi 980 (BR); Équateur, Eala, $0^{\circ} 4^{\prime} \mathrm{N}, 18^{\circ} 17^{\prime} \mathrm{E}$, Goossens 1639 (BR, K); Bokela, Hulstaert 1395 (BR); Eala, $0^{\circ} 4^{\prime} \mathrm{N}, 18^{\circ} 17^{\prime} \mathrm{E}$, Lebrun 6812 (BR); Yangambi, 047' N, $21^{\circ} 28^{\prime}$ E, Lejoly 81/631 (BR); Eala, $0^{\circ} 4^{\prime} \mathrm{N}, 18^{\circ} 17^{\prime} \mathrm{E}$, Lemans 220 (BR, K, P); Eala, route de Coq, 31' N, 19²' E, Léonard 1090 (BM, BR, C, K); Yangambi, $0^{\circ} 47^{\prime} \mathrm{N}, 21^{\circ} 28^{\prime} \mathrm{E}$, Maudoux 455 (BR), 574 (BR); Dundusana, $2^{\circ} 57^{\prime} \mathrm{N}, 22^{\circ} 16^{\prime}$ E, Mortehan 48 (BR); Équateur, Forestier Central, Dundusana, 2 ${ }^{\circ} 57^{\prime} \mathrm{N}$, $22^{\circ} 16^{\prime} \mathrm{E}$, Mortehan 931 (BR); Patambalu, $2^{\circ} 12^{\prime} \mathrm{S}, 18^{\circ} 16^{\prime} \mathrm{E}$, Tailfer 103 (BR, K); Alumombazi (Mongala), 150' S, 1651' E, Thonner 198 (BR); Eala, champ $31,0^{\circ} 4^{\prime} \mathrm{N}, 18^{\circ} 17^{\prime} \mathrm{E}$, Vanhelmont 3 (BM, BR, K, P).

GABON: Estuaire, Cap Esterias, $0^{\circ} 37^{\prime}$ N, $9^{\circ} 20^{\prime}$ E, Klein 46 (A, BR, K, P).

Discussion-Daniellia pynaertii may be distinguished from other species by the character combination of a pubescent midrib on the abaxial face of leaflets, glabrescent pedicels and staminal filaments united at the base for only $0.5-1 \mathrm{~mm}$ (Table 1 ; Fig. 13L).

While Daniellia pynaertii may be confused with D. pilosa, it differs in having a pair of glands at the point of insertion of each pair of leaflets (usually lacking in D. pilosa) and generally a longer pedicel 8-13(-14) mm long, instead of 7-11 mm in D. pilosa. Morphologically, Daniellia pynaertii is similar to D. alsteeniana, but they may be distinguished, at least in some cases, by the presence and position of crateriform gland(s) on the lower surface of the leafets. In the former, a single crateriform gland is present $2-8 \mathrm{~mm}$ from the petiolule, not $1-3 \mathrm{~cm}$ from the petiolule as in $D$. alsteeniana which sometimes bears a second crateriform gland on a lateral vein in the distal half of the leaflet. (Table 1).

Daniellia pynaertii shows considerable variation in leaf blade shape and size. Immature leaflets may be lanceolate and papyraceous (Lemans 220, Corbisier 1032), but become oblong and coriaceous when mature. Some of the leaf variation both within and between collections may be attributable to age and position on the plant. We have also found some variability in the pod which is usually rounded but in one specimen appears to be shortly beaked (Madoux 574). A beaked pod is characteristic of $D$. soyauxii, a species from which $D$. pynaertii may be distinguished vegetatively by the presence of glands at point of insertion of the leaflets (lacking in D. soyauxii), a pubescent midrib on the lower leaflet surface (glabrous in D. soyauxii), and in flower by glabrescent pedicels (always velvety in $D$. soyauxii) and staminal filaments fused at most for $1 \mathrm{~mm}$ at the base (ca. $5 \mathrm{~mm}$ in D. soyauxii; Table 1).

In his description of Daniellia mortehanii, De Wildeman (1920, p. 260) referred to a single collection: "Dundusana, décembre 1913 (Mortehan, n. 931...)". Because this author does not indicate this specimen as the type nor indicate where it was deposited it is not clear that it is the holotype. Léonard (1950, p. 118) selected Mortehan 931 (BR) as the lectotype of D. Mortehanii. However, Mortehan 931 is a mixed collection with flowers matching those of $D$. pynaertii and leaves probably belonging to a species of Afzelia. We have selected here the flowers of Mortehan 931 (BR) specimen as the lectotype of $D$. mortehanii and placed the name in synonymy under D. pynaertii.

The holotype of Daniellia ealaensis (Corbisier 1032) was deposited in "Herb. Mus. Congo, Tervueren". The Herb. Mus. Congo, Tervueren collections were transfered to BR in 1934, hence the BR specimen is considered to be the holotype. Differences in the leaflet morphology of Corbisier 1032 due to immaturity lead to previous authors recognizing this specimen as a species in its own right.

When Hutchinson and Dalziel (1928a, p. 382) published Daniellia pubescens they cited: "Nigeria: Southern Provinces; Lagos Colony, Moloney". Since the authors neither indicated if the specimen was the type nor in which herbarium it was deposited, no holotype was designated. Léonard (1950, p. 112) said that the type material of $D$. pubescens species was "Lagos, mai 1883, Moloney (typus D. pubescens, Herb. Kew)" and in so doing he selected as lectotype Moloney s. n. (K). Hutchinson and Dalziel (1928a, 1928b) published D. pubescens species in two works, first in the "Bulletin of Miscellaneous Information, $K e w$ " which appeared in May and then in the "Flora of West tropical Africa" which appeared in July. Therefore, the correct place of publication for D. pubescens is Hutchinson and Dalziel (1928a). Similarly, they also duplicated publication of the name $D$. oliveri.

8. Daniellia soyauxiI (Harms) Rolfe, Bull. Misc. Inform. Kew 1912: 97. 1912. Cyanothyrsus soyauxii Harms, Bot. Jarhb. Syst. 26: 270. 1899.-TYPE: GABON. Libreville, SibangeFarm, 22 July 1880, Soyaux 101 (type: B+?). NEOTYPE: GABON. Libreville, Sibange-Farm, 2 June 1880, Soyaux 90 (designated here: K!; isoneotype: P!).

Tree ca. $35 \mathrm{~m}$ tall and 50-120 cm dbh. Twigs and branches glabrescent, short white hairs present on young parts, budscale scars clearly visible on the inflorescence branches, less clearly so on the vegetative branches. Leaves 18-27 × (6-)8-12 $\mathrm{cm}, 6-9$-jugate, largest leaflet situated at about the midpoint of the leaf; stipules only seen on young twigs 3.5-4.5 × $2 \mathrm{~mm}$, lanceolate, revolute, glabrous, accrescent ca. $97 \times 11 \mathrm{~mm}$, pubescent within, glabrous exterior, caducous; petiole 6-12(-14) $\mathrm{mm}$ long; subterete, pubescent to glabrescent; petiolules1.5-4 $\mathrm{mm}$ long; rachis 12-16(-18) cm long, subterete and shallowly channeled at the base becoming quadrangular distally, slightly pubescent to glabrescent, without glands at the insertion of the leaflets, terminating in a small scale 1-3 mm long, glabrous or with few short hairs; leaflets subopposite basally, opposite distally, coriaceous, minutely mucronate, with 8-16 pairs of main lateral veins, translucent gland dots dense, glabrous on both faces, with a small gland on the narrower side of the lamina, near the midrib and the petiolule, midrib prominent 


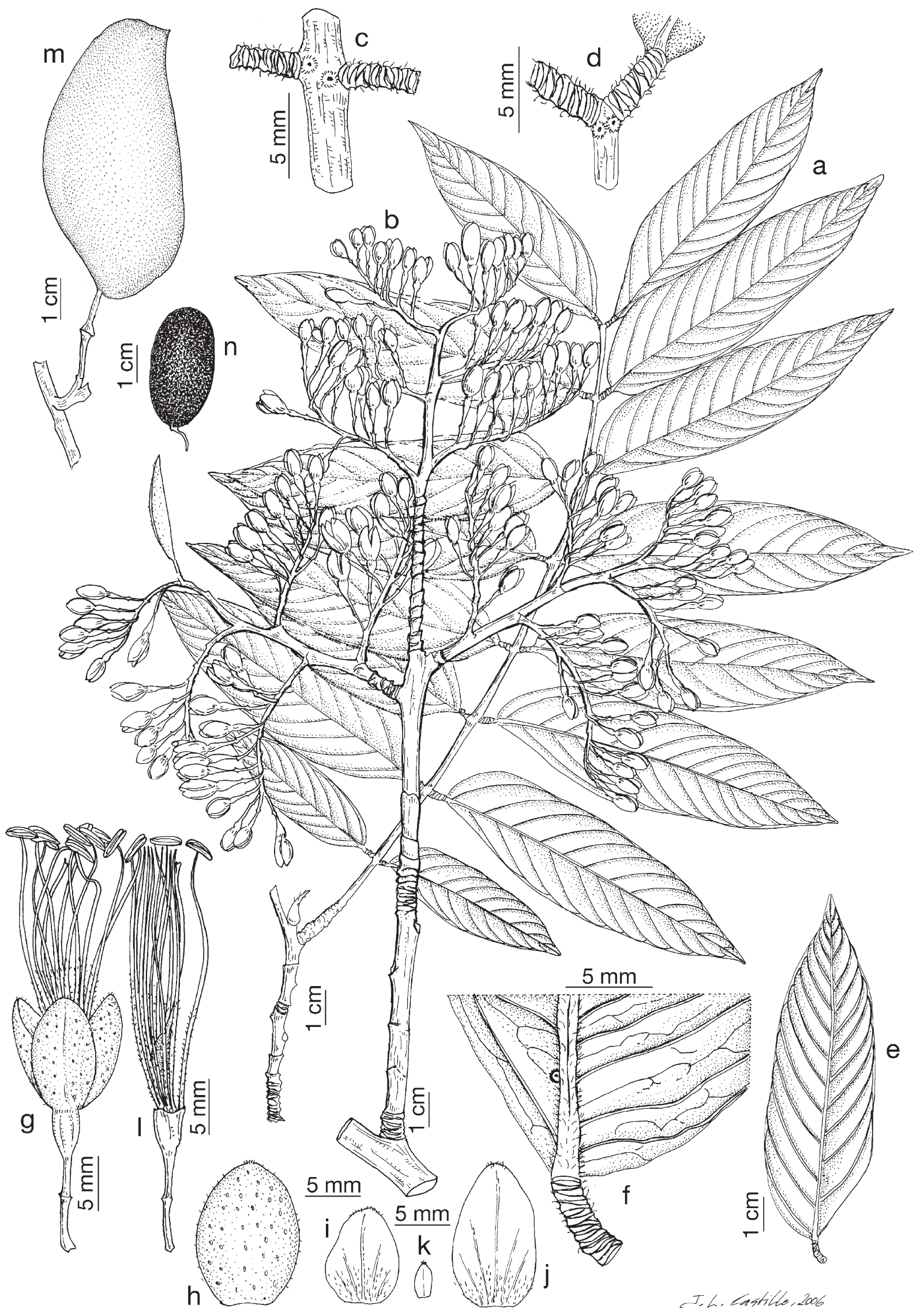

FIG. 13. Daniellia pynaertii. a. Twig with leaves. b. Inflorescence. c. Insertion of basal pair of leaflets. d. Apical pair of leaflets insertion. e. Leaflet, adaxial surface. f. Leaflet gland, abaxial surface. g. Flower. h. Sepal seen from exterior. i. Adaxial petal seen from exterior. j. Lateral petal seen from exterior. k. Abaxial petal seen from exterior. 1. Flower without perianth. m. Pod. n. Seed. [Based on: a, c-f, Léonard 1090 (BR); b, g-1, Leemans 220 (K); m-n, David Harris \& Fay 938 (MO-3845001)]. 
on the abaxial face, terete; basal leaflet 3.5-7 $\times 1.5-2.7 \mathrm{~cm}$, oblong, base rounded and asymmetric, apex acuminate with an acumen 7-11 mm long, base cuneate and asymmetric; apical leaflet 7-9 × 2-3.5 cm, lanceolate-elliptic, base cuneate, apex acuminate with an acumen 3-10 mm long; largest leaflet $6-8(-10) \times 2-3 \mathrm{~cm}$, oblong-elliptic, base rounded and asymmetric, apex acuminate with an acumen 6-13(-14) mm long. Inflorescence a compound raceme, 3-6(-10) cm long, peduncle 5-7 mm long, with 5-6 lateral branches $2.5-6.5 \mathrm{~cm}$ long and 22-23-flowered; rachis long velvety; bracts ca. $7 \times 6 \mathrm{~mm}$, caducous, ovate-oblong, pubescent towards the lateral margins, inner face pubescent; pedicel 3-6 mm long, not twisted at the base, velvety pubescent to glabrescent, accrescent in fruit; bracteoles 7-8 × ca. $4.5 \mathrm{~mm}$, caducous, obovate-elliptic, pubescent exterior more densely so towards the margins, inner face pubescent in the central area, inserted at the midpoint of the pedicel. Receptacle $1.5-3 \times 1.5-4 \mathrm{~mm}$, ciliate within; pedicel plus receptacle $5-9 \mathrm{~mm}$ long; flower bud 3-5 mm wide. Flowers pale blue. Sepals 4, 6-10 × 3.5-5 mm, obovate, ciliate along the margins and a tuft of hairs at the apex, gland dots present on external surface. Petals 5; adaxial petal 5-6 × 3-4 mm, oblong, pubescent at the base and near the apex of both surfaces; lateral petals $6.5-7 \times 5-5.5$, oblongovate, velvety on margins and near the base externally, some gland dots just visible on external face; abaxial petals 1.2-1.5 $\times$ 0.75-1.5 mm wide, ovoid, glabrous. Stamens 10, filaments 11-20 $\mathrm{mm}$ long, 9 united at the base for ca. $5 \mathrm{~mm}$, pubescent at least on the lower two-thirds; anthers 1.3-1.7 mm long. Ovary 3.5-5 mm long, oblong, a few hairs along the sutures, slightly grainy, gland dots not present, stipe $2-3.5 \mathrm{~mm}$ long, densely pubescent. Pod 7-8 $\times 3.5-4.5 \mathrm{~cm}$, oblong-elliptic, asymmetric, small beak present, densely pubescent mainly along the margin, stipe 9-11 mm long (in fruit), pedicel ca. $16 \mathrm{~mm}$ long (in fruit). Seeds not seen. Figure 14 .

Phenology-Flowering is recorded from April to June, fruiting from September to December.

Distribution and Habitat-Cameroon and Gabon; in tropical rain forest near water sources, 30-420 m. Figure 10.

Specimens Examined-CAMEROON: Douala-Edea, ca. km 40, Letouzey $4021(\mathrm{P})$.

GABON: env. du Ponte de Orvendo, sur le Komo, Guilet 30 (P); env. Libreville, $0^{\circ} 23^{\prime} \mathrm{N}$, 9²7' E, Klaine 2954 (P); Ogooué-Maritime, Loango N. P., $1^{\circ} 57^{\prime}$ S, 9²9' E, Mouandza 260 (WAG); Ogooué-Maritime, Rabi-Kounga, $1^{\circ} 54^{\prime} \mathrm{S}, 9^{\circ} 56^{\prime} \mathrm{E}$, Wieringa \& Epoma 1627 (WAG); Moyen-Ogooué, $26 \mathrm{~km}$ ENE of Lambaréné, $6 \mathrm{~km}$ ENE of Bellevue, $0^{\circ} 36^{\prime} \mathrm{S}, 10^{\circ} 26^{\prime} \mathrm{E}$, Wieringa \& Haegens 2614 (G, WAG); Ogooué-Maritime, Rabi, $11 \mathrm{~km}$ on road to Divangui, 154' S, 957' E, Wieringa \& Nzabi 2800 (WAG); Ngounié, Massif de Koumounabouali, $1^{\circ} 21^{\prime}$ S, $10^{\circ} 27^{\prime}$ E, Wilde \& Wilde-Bakhuizen 11717 (WAG).

Discussion-Daniellia soyauxii is restricted to central Africa. As is the case for several other species, it is known only from a few specimens; however it may be distinguished from all other species by its unique combination of characters, including the absence of glands at the insertion of each pair of leaflets and the possession of a glabrous midrib on abaxial face of the leaflets. Other useful distinguishing characters include the pod, which has a small pubescent beak at the apex (seen elsewhere only in D. oliveri) and the sepals which are glabrous except for their ciliate margin and a tuft of hairs at the apex (only D. oblonga shares this indumentum pattern; Table 1).

Daniellia soyauxii can be confused with $D$. pilosa but features allowing for the distinction of these two species are provided under the discussion of $D$. pilosa. Daniellia soyauxii is also closely related to $D$. ogea from which it can be distinguished by the absence of glands at the insertion of the pairs of leaflets and glabrous sepals.

When Harms described Cyanothyrsus soyauxii, the basionym of Daniellia soyauxii, he referred to only one collection in the description, Soyaux 101 which was probably housed at B (Léonard 1950, p. 105) where many types were destroyed during World War II. No duplicate material has been found and it is necessary to designate a neotype. In the protologue the locality was given as "Gabun: Sibange-Farm (Soyaux n. 101. 22 Juli 1880)". The specimen Soyaux 90 (K!, P!) from the same locality and year, has a hand written label by Harms made in January 1911 on which he identifies the specimen as Cyanothyrsus soyauxii. Léonard (1950, p. 105) noted that Soyaux 90 matches the original description except for the presence of indumentum on the ovary which Harms had reported as glabrous. Having re-examined the ovaries, we found the ovary to be glabrescent save for a few hairs along the sutures and the stipe pubescent. We have selected Soyaux 90 (K, P) as the neotype for the name Cyanothyrsus soyauxii.

9. Daniellia thurifera Benn., Pharm. J. Trans. 14: 253. 1854.-TYPE: SIERRA LEONE. Without locality: "resinam fragrantem Bungo s. Bungo dictam exsudans", Daniell s. n. (lectotype: designated by Léonard 1950: 99, $\mathrm{BM}$ ).

Daniellia caillei A. Chev., Explor. Bot. Afrique Occ. Franç.: 230. 1920.-TYPE: GUINEA. Route de Longuery, 1 Dec. 1905, Caille in Chevalier 14827 (lectotype: designated by Léonard 1950: 99, K!; isolectotype: P!).

Tree ca. $35 \mathrm{~m}$ tall and ca. $40 \mathrm{~cm}$ dbh. Twigs and branches glabrous, bud-scale scars clearly visible on the inflorescences branches, less clearly so on the vegetative branches. Leaves 19-23(-27) × 12-16(-28) cm, 6-9-jugate, largest leaflet situated below the midpoint of the leaf; stipules only seen on young twigs $3-10 \times 1.5-3 \mathrm{~mm}$, revolute, glabrous to puberulous mainly in the margin; accrescent $10-11(-15) \times 0.9-1(-1.6) \mathrm{cm}$, caducous; petiole (13-)17-34(-54) mm long, terete, shallowly channeled, glabrous, with a pair of small rounded sunken glands at the point of insertion of the basal pair of leaflets; petiolules 4.5-8 $\mathrm{mm}$ long, rachis (11-)13-17(-27) cm long, subterete and shallowly channeled at least at the base, but sometimes over its entire length, becoming quadrangular distally, glabrous, without glands or with glands at the insertion of the basal pairs of leaflets (sometimes with gland on abaxial face), terminating in a small scale $0.5 \mathrm{~mm}$ long, glabrous; leaflets subopposite basally, opposite distally, coriaceous, slightly mucronate, with 10-25 pairs of main lateral veins, densely set with translucent gland dots, completely glabrous on both faces, with two small glands, one near the midrib, on the narrower lamina side, the second one smaller and situated on a lateral vein, midrib prominent on the abaxial face, terete; basal leaflet 4-8 × 2-3.5 cm, ovate-elliptic, base rounded and asymmetric, apex acuminate with an acumen 5.5-11(-13) mm long; apical leaflet 6-10(-14) × 2-3(-5) cm, oblong-lanceolate, base cuneate, asymmetric, apex acuminate with an acumen (3.5-) 5-15 mm long; largest leaflet 7.5-12(-18) × 2.5-6 cm, oblongelliptic, base rounded and asymmetric, apex acuminate with an acumen (5-)7-17 mm long, petiolule 4.5-8 mm long, 1-2(-3) $\mathrm{mm}$ wide. Inflorescence a compound raceme (6-)9-11(-15) $\mathrm{cm}$ long, peduncle 8-23 mm long, with 6-10 lateral branches 5.5-7.5(-9) cm long and 8-12-flowered; rachis glabrous; pedicel 8-11(-17) mm long, slightly twisted at the base, glabrous, accrescent in fruit; bracteoles not seen, caducous, inserted 


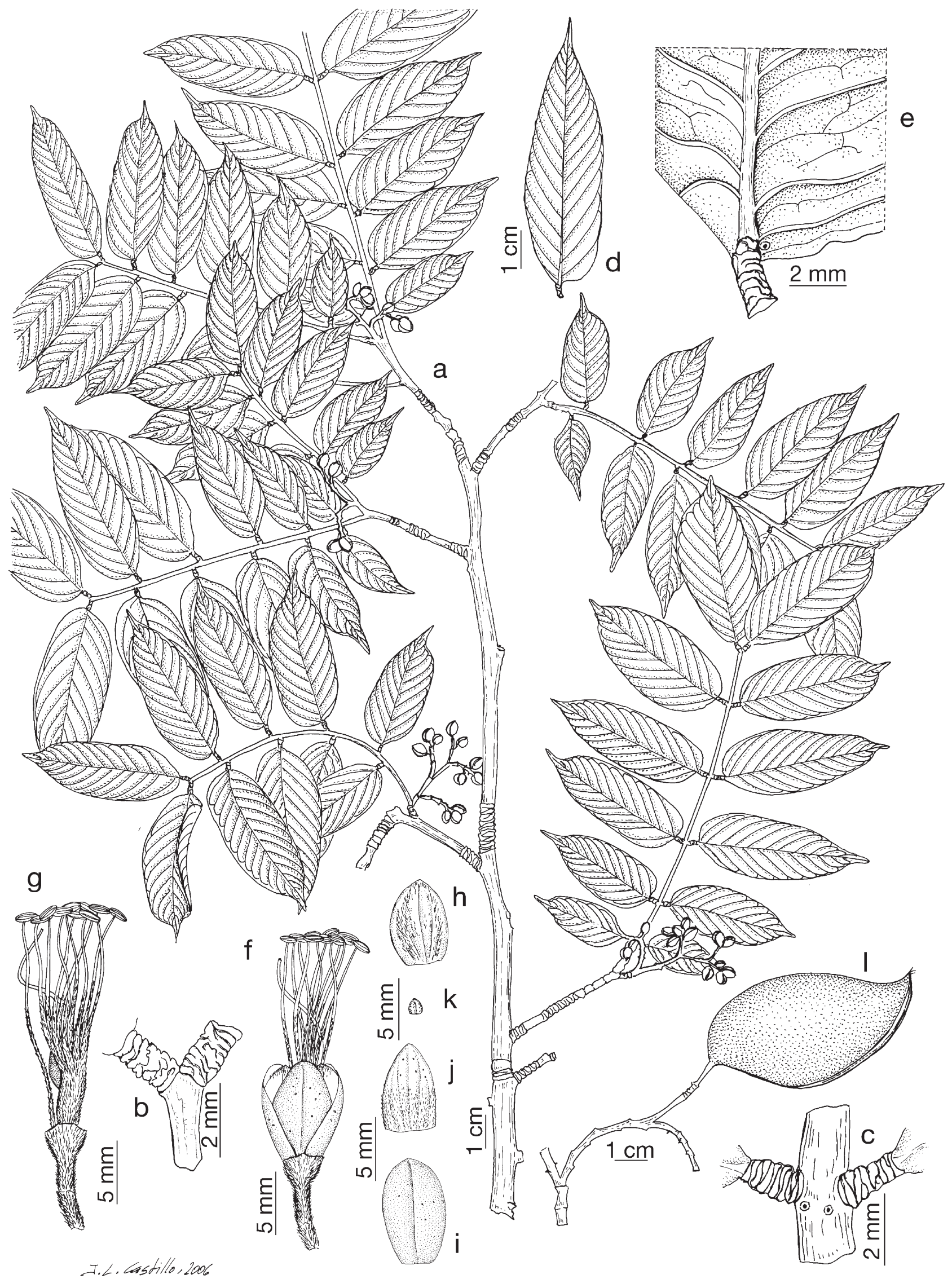

Fig. 14. Daniellia soyauxii. a. Twig with leaves and immature inflorescences. b. Apical pair of leaflets insertion. c. Insertion of basal pair of leaflets. d. Leaflet, abaxial surface. e. Leaflet gland, abaxial surface. f. Flower. g. Flower without perianth. h. Adaxial petal seen from exterior. i. Sepal seen from exterior. j. Lateral petal seen from exterior. k. Abaxial petal seen from exterior. 1. Pod. [Based on: a-c, Wieringa \& Haegens 2614 (WAG-110746); d, e, 1, Wieringa \& Epoma 1627 (WAG-110761); f-k, Klaine 2954 (P)]. 
at the midpoint of the pedicel. Receptacle 4.5-6 × 3.5-5 mm, ciliate within; pedicel plus receptacle $13-16(-23) \mathrm{mm}$ long; flower bud 6-9 $\mathrm{mm}$ wide. Flowers with pale green sepals and white to yellow petals. Sepals 4, (14-)17-20 × 6-11(-13) mm, oblong, glabrous but with a ciliate margin, with few gland dots on external surface. Petals 5; adaxial petal 12-15 × 5-8 $\mathrm{mm}$, oblong, slightly falcate, conduplicate, glabrous except \pm pubescent at the apex and within in the basal part, with few gland dots on external face; lateral petals 12-16 × 7-13 mm, oblong, rounded, velvety within, pubescent on external face and margins, with few gland dots on external face; abaxial petals 1-3 × 0.6-1.5 mm, oblong, almost triangular, glabrous or with a few hairs at the apex. Stamens 10, filaments 30-43 mm long, 9 united at the base for $4-8 \mathrm{~mm}$, pubescent at least on the two-thirds; anthers 2-4 mm long. Ovary 7-10 mm length, 3.5-4.5 mm wide, oblong-rombic, glabrous, slightly grainy rough, stipe 3-6(-8) $\mathrm{mm}$ long, glabrous; style $21-24 \mathrm{~mm}$ long, glabrous; stigma rounded. Pod 7-9 × 3.5-5 cm, one margin straight, the other more or less falcate, glabrous, stipe 8 $\mathrm{mm}$ long, pedicel $25 \mathrm{~mm}$ long. Seeds 17-32 × 10-16 × 2.5-4.5 $\mathrm{mm}$, oblong, smooth, deep red to brown; funicle ca. $14 \mathrm{~mm}$ long. Figure 15.

Phenology-Flowering is recorded from August to December; fruiting from January to July.

Distribution and Habitat-West tropical Africa; primary and secondary forest, riparian forest and grassy fields; 10-380 m. Figure 7.

Vernacular Names-Ivory Coast: Kouan'ga. Liberia: Whoe. Sierra Leone: Gbessei, gum called Bungo n Bungo.

Uses-Wood for canoes; gum used in cosmetics, also in traditional medicine (Burkill 1995).

Representative Specimens Examined-GUINEA BISSAU: Kindia, Friguiagbé, Condoyon, 9 9 57' N, 1256' W, Chillou 1294 (BR, C, COI, K, P); Tombali, Catió, 11 $17^{\prime}$ N, 15¹5' W, Espirito Santo 2099 (BR, K, LISC, P, WAG); env. de Kindia, bords Killissi, Jacques Félix 415 (P); FrigmagbéBambanya, Pobéguin 45 (P).

IVORY COAST: Lagunes, Abidjan, $5^{\circ} 25^{\prime} \mathrm{N}, 4^{\circ} 2^{\prime} \mathrm{W}$, Adjin 13 (G); Alépé, sur 1'Attié, 5⒉ $9^{\prime} \mathrm{N}, 3^{\circ} 39^{\prime} \mathrm{W}$, Chevalier 16240 (P); Chevalier 17240 (P); Abaisso dans Lanvi, Chevalier 17855 (P); Yapo, dans la gare, $5^{\circ} 48^{\prime} \mathrm{N}, 4^{\circ} 8^{\prime}$ W, Chevalier B.22.360 (K, P); sur le chemin de fer au km 52, Fleury 11 (B, P); Adidjan, Banco Forest Reserve, $5^{\circ} 23^{\prime}$ N , $4^{\circ} 3^{\prime}$ W, Koning 2781 (WAG); Banco, $5^{\circ} 23^{\prime} \mathrm{N}, 4^{\circ} 3^{\prime} \mathrm{W}$, Martineau 338 (BR); Lagunes, Adiapo-Doumé, $5^{\circ} 20^{\prime} \mathrm{N}, 4^{\circ} 7^{\prime}$ W, Mission d'Ètude de la Pharmacoppe African s. n. (G); Adiapo-Doumé, 5²0' N, $4^{\circ} 7^{\prime}$ W, Roberty 12396 (G, Z); Forêt d'I.D.E.R.T., along the Lagune Ebrié, $5^{\circ} 20^{\prime} \mathrm{N}, 4^{\circ} 1^{\prime} \mathrm{W}, \mathrm{W}$. J. Wilde 625 (BR, K, WAG).

LIBERIA: Monrovia, along Dukwai river, $6^{\circ} 18^{\prime} \mathrm{N}, 10^{\circ} 47^{\prime} \mathrm{W}$, Cooper 77 (A, BM, K, NY); Cooper 95 (A, BM, K, NY); Cooper 322 (A, BM, K, NY); Cooper 350 (A, BM, K, NY); Bassa, $4^{\circ} 47^{\prime} \mathrm{N}, 8^{\circ} 24^{\prime} \mathrm{W}$, Voorhoeve 675b (WAG); Suwah, Voorhoeve 1320 (WAG); Bong, Bong Range, $32 \mathrm{~km} \mathrm{~N}$ of Kakata, $6^{\circ} 49^{\prime} \mathrm{N}, 10^{\circ} 17^{\prime} \mathrm{W}$, Voorhoeve 753 (WAG).

NIGERIA: Lagos, $6^{\circ} 27^{\prime} \mathrm{N}, 3^{\circ} 23^{\prime} \mathrm{E}$, Moloney s. n. (K); Western Province, Moor Plantation, Ibadan, Van Eijnatten 1341 (WAG).

SIERRA LEONE: Coumandi-Gegaru, Aylmer 256 (K); road Kent, $8^{\circ} 9^{\prime}$ N, 139' W, Morton 197 (K, WAG); Freetown, Botanic Garden, Fourah Bay College, $8^{\circ} 29^{\prime}$ N, $13^{\circ} 14^{\prime}$ W, Morton 1550 (K, WAG); Eastern, Kenema, Nongowa, Samai 261 (K).

Discussion-Daniellia thurifera may be distinguished from all other members of Daniellia subgen. Daniellia by the lack of pubescence on the petiole, rachis, leaflets, pedicels, and sepals with the exception of D. klainei from which it can be distinguished using other characters (discussed in detail under D. klainei). Daniellia thurifera is the only species in which the adaxial petal is approximately equal in length to the lateral petals. Although morphologically similar to D. oblonga, vegetative specimens can be distinguished by the presence of glands at the point of insertion of each pair of leaflets in D. oblonga as compared to presence only between the prox- imal pair of leaflets in D. thurifera. In flowering specimens, $D$. thurifera is characterized by a glabrous inflorescence rachis (slightly pubescent in D. oblonga; Table 1).

Like other species, Daniellia thurifera is variable in leaflet shape, size and texture. Léonard (1950, p. 100) reported field observations made by Melville indicating that older trees of $D$. thurifera have smaller leaflets. Morphological variation in leaflets observed during the course of this study vary from small (ca. $8 \times 3 \mathrm{~cm}$ ), lanceolate and coriaceous (Afzelius s. n.) to larger (ca. $18 \times 6 \mathrm{~cm}$ ), oblong and papyraceus (Daniell s. $n$.).

Bennett (1854, p. 253) described D. thurifera, citing Daniell s. $n$. in the protologue but neither indicated if this specimen was the type, nor in which herbarium it was deposited. Later, Léonard (1950, p. 99) stated that the type material of this name was "Sierra Leone: Daniell (typus, Brit. Mus.; dessin du type Herb. Kew)" and selected as the lectotype Daniell s. n. (BM).

When Chevalier (1920, p. 230) described D. caillei, he did not formally designate a type but gave details of a single collection: "Route de Longuery, au bord du marigol, 1er décembre 1905, n 14827 [O. Caille]". Subsequently, Léonard (1950, p. 99) reported that the type material of this species was "Route de Longuery, Caille in Chevalier 14827 (typus D. caillei; 1 foliole à Kew)" and by mean of this he selected as lectotype Caille in Chevalier $14827(\mathrm{~K})$. The isolectotype located in $\mathrm{P}$ (where the original set of Chevalier collections was deposited) is a two sheet specimen with leaves and inflorescences.

II. Daniellia subg. Paradaniellia (Rolfe) Baker, Leg. Trop. Afr. 695. 1930.-TYPE: D. oliveri (Rolfe) Hutch. \& Dalziel

Paradaniellia Rolfe, Bull. Misc. Inform. Kew 1912: 96. 1912.

Flowers with 5 petals, one larger petal (lateral one), 7-13 $\mathrm{mm}$ long, and the other 4 reduced, 1-3 mm long (rarely 2 large petals (lateral ones), the second one $8 \mathrm{~mm}$ long, and 3 reduced). Filaments free, glabrous (rarely few hairs at the base). Seeds obovate-elliptic.

10. Daniellia oliveri (Rolfe) Hutch. \& Dalziel, Bull. Misc. Inform. Kew 9: 382. 1928. Paradaniellia oliveri Rolfe, Bull. Misc. Inform. Kew 1912 (2): 96. 1912.-TYPE: SENEGAMBIA. Without locality, Heudelot 364 (lectotype: designated by Léonard 1950: 120, K!; isolectotype: P!).

Tree ca. $20 \mathrm{~m}$ tall and ca. $2 \mathrm{~m} \mathrm{dbh}$, with grey and cylindrical bole. Twigs and branches glabrous, bud-scale scars clearly visible on the vegetative and inflorescences branches. Leaves (26-)33-46(-61) × 19-22(-26) cm, (3-)6-11-jugate, largest leaflet situated at about the midpoint of the leaf; stipules only seen on young twigs 3.5-6.5(-9) $\times 2.5-4 \mathrm{~mm}$, revolute, glabrous, accrescent 5.5-13 × 5-8 mm, caducous; petiole (20-)25-35(-54) $\mathrm{mm}$ long, 3.5-5(-7) mm diameter, subterete, shallowly channeled, glabrous to glabrescent, with a pair of small rounded sunken glands at the point of insertion of the basal pair of leaflets; petiolules 3-15 mm long; rachis (17-)24-33(-52) cm long, subterete and shallowly channeled at the base becoming quadrangular distally, slightly pubescent to glabrescent, with a pair of glands at the insertion of each pair of leaflets (sometimes thickened by glands on abaxial face), terminating in a small scale $0.5-1 \mathrm{~mm}$ long, sparsely puberulous; leaflets opposite, coriaceous to papyraceous, margin slightly undulate, mucronate, with 9-17 pairs of main lateral veins, translucent gland dots sparse, slightly pubescent or glabrescent on the adaxial face, and densely pubescent (mainly on midrib) to glabrescent on the abaxial face, with two small crateriform glands, one on the narrower side of the lamina near the midrib, the other on a lateral vein in the distal lamina side, midrib prominent on the abaxial face, 


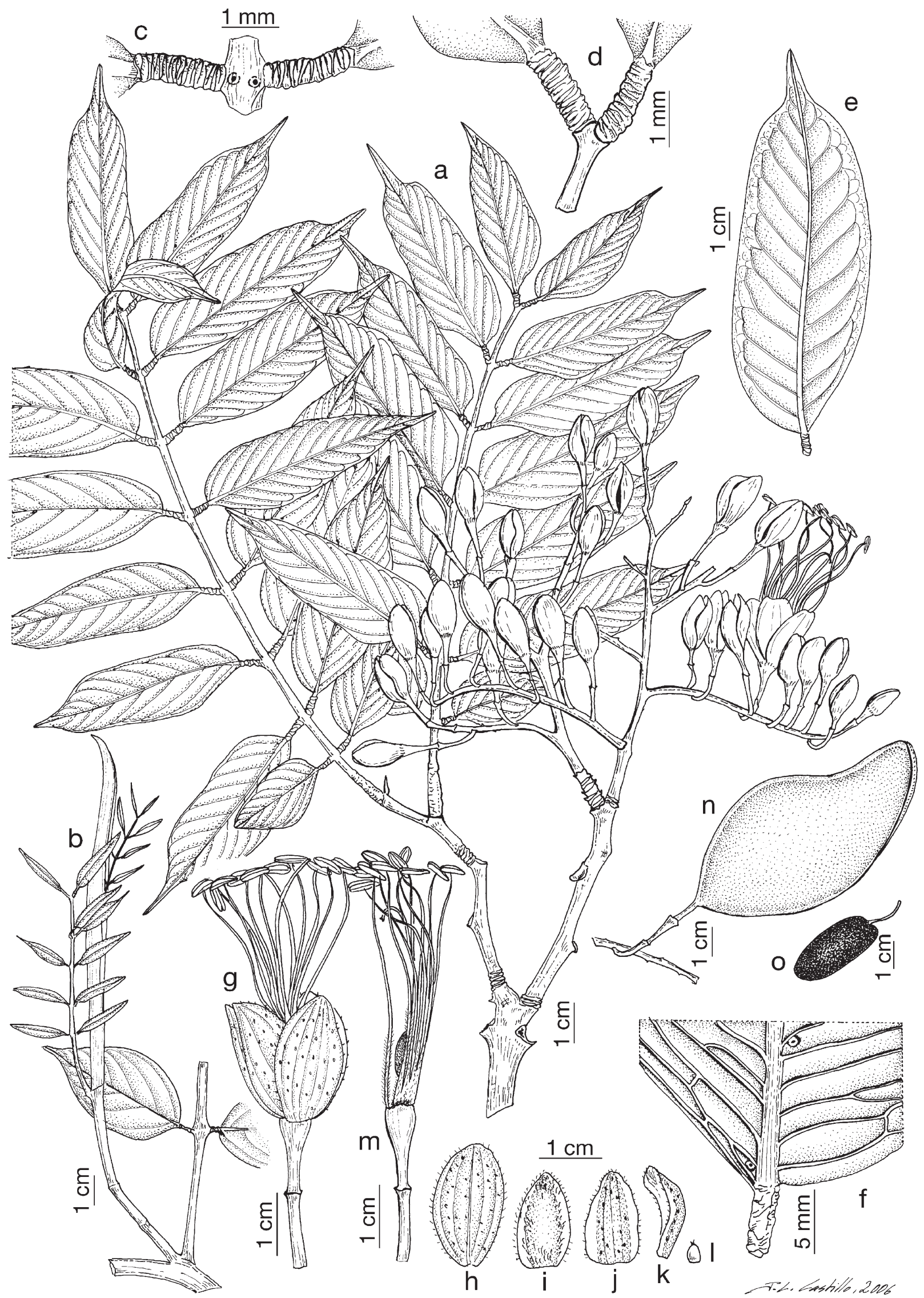

Fig. 15. Daniellia thurifera. a. Twig with leaves and inflorescence. b. Stipule. c. Insertion of basal pair of leaflets. d. Apical pair of leaflets insertion. e. Leaflet, adaxial surface. f. Leaflet glands, abaxial surface. g. Flower. h. Sepal seen from exterior. i. Lateral petal seen from inside. j. Lateral petal seen from exterior. k. Adaxial petal seen from lateral side. l. Abaxial petal seen from exterior. m. Flower without perianth. n. Pod. o. Seed. [based on: a, c-m, W. J. Wilde 625 (WAG-09575); b, n-o, Espirito Santo 2099 (LISC)]. 
terete, crested over its entire length; basal leaflet 8-11 × 5-6 cm, oblong-ovate, base asymmetric, apex acuminate with an acumen 4.5-8 mm long; apical leaflet 5.5-11 × 4-6 cm, lanceolate, base cuneate, asymmetric, apex acuminate with an acumen 6-7.5(-12) mm long; largest leaflet $10-15(-21) \times 5-7(-10) \mathrm{cm}$, oblong-ovate, base rounded and asymmetric, apex acuminate with an acumen (5-)7-13(-16) mm long. Inflorescence a compound raceme, 15-20(-25) cm long, peduncle (6-)9-14(-20) mm long, with 6-16 lateral branches (5-)11-15(-21) cm long and 12-28-flowered; rachis glabrescent to tomentose; pedicel 7-13 mm long, not twisted at the base, glabrous, accrescent in fruit; bracteoles, ca. $5 \times 2.8 \mathrm{~mm}$, caducous obovate, with a tuft of hairs at the apex, inserted below the midpoint of the pedicel. Receptacle $6-9 \times(2.5-) 3-5 \mathrm{~mm}$, ciliate within; pedicel plus receptacle 13-22 mm long; flower bud 6-11 mm wide. Flowers with green sepals and white to pale cream petals. Sepals 4, (12-)14-17 × (5-)7-10 mm, oblong, glabrous except for ciliate margins, smooth, gland dots usually absent. Petals 5; adaxial petal, one lateral petal and abaxial petals $1-1.5(-3) \times 0.6-1$ (-2) $\mathrm{mm}$, ovate-elliptic, glabrous, other lateral petal, (7-)10-12 $\times$ 2-6 mm, elliptic, glabrous except for a few hairs at the base and the apex, a few translucent gland dots present on the external face. Stamens 10, filaments (18-)29-31(-34) mm long, not fused, glabrous or occasionally with a few hairs at the base; anthers 3-5(-6) mm long, sometimes pubescent. Ovary 5.5-8 $\mathrm{mm}$ long, oblong-lanceolate, glabrous, smooth, gland dots absent, stipe (1.5-)4-5(-7) mm long, glabrous; style (12-)17-28 $\mathrm{mm}$ long, glabrous; stigma rounded. Pod 6-10 × 3-4.5 cm, lanceolate, sometimes shortly beaked, glabrous, stipe 9-12 mm long. Seeds 20-27 × 15-16 × 5-6 mm, obovate-elliptic, smooth, dark brown; funicle 8-18 mm long. Figure 16.

Phenology-Flowering is recorded from October to March (except for a single specimen recorded flowering in June); fruiting from January to June.

Distribution and Habitat-Savannah lands south of Sahel from Senegal to South Sudan; savannah lowland, grassland and sandy soils; sea level-1,500 m. Figure 4.

VernacularNames_Cameroon:Kaherlahi(Foulbé),Karlawal Tutu (Mboum). C. African Republic: Bidda, Birolo (Landa), Mokala (Lissango). Chad: Bita (M'Baïe). Congo (Kinshasa): Bamvutule, Giwi. Gambia: Santangho. Guinea Bissau: Kévé (Fonde), Pan Incenso (Portuguese), Uambo (Bijagó). Ivory Coast: Santan (Baoulé). Mali: Kedte, Sanau. Niger: Falmeï. Nigeria: Dunchi. Bambora (Ntomi), Bu Balinab, Santam (Woloff), Tievi (Tounvancheur). Sudan: Bito, Bú (Zande).

Uses-Wood is used for furniture, boat, and canoe building, bark is used for medicinal purposes, and seeds are said to be eaten (Aubréville 1950; Burkill 1995).

Representative Specimens Examined-BENIN: Zou, Agbangnizoun, Siwé-Zounmè, $7^{\circ} 3^{\prime}$ N, $1^{\circ} 58^{\prime}$ E, Adjakidjè et al. 4025 (WAG); Oaja-Ouéré, Dahomey, Poisson 21 (P).

BURKINA FASO: Obervolta, Strasse von Orodara und von Sikasso ungefähr $25 \mathrm{~km}$ westl von Bobo, Garnier 73/40 (B); Haute-Volta, Dinderesso, $11^{\circ} 14^{\prime} \mathrm{N}, 4^{\circ} 26^{\prime} \mathrm{W}$, Mariaux $413(\mathrm{P})$.

CAMEROON: Monkong, $10^{\circ} 34^{\prime} \mathrm{N}, 14^{\circ} 1^{\prime} \mathrm{E}$, Barreteau 14 (P); MarouaMéri, km 15, 10² $2^{\prime} \mathrm{N}, 14^{\circ} 15^{\prime} \mathrm{E}$, Bonny 2 (BR, K, P); Maroua, De Wit 7017 (WAG); Foumban, 543' N, 1055' E, Jacques Félix 3102 (P); North Province, près Minim, $6^{\circ} 58^{\prime} \mathrm{N}, 12^{\circ} 52^{\prime} \mathrm{E}$, Letouzey $2587(\mathrm{P}, \mathrm{WAG})$; N'Gaundéré, Lisowski B-1419 (BR); 9 km NW of Garona, Bulai, 55' N, 143'ㄹ E, Lowe 3342 (K); Maroua town, $10^{\circ} 35^{\prime}$ N, $14^{\circ} 19^{\prime}$ E, Mekey s. n. (K); NgaoundéréMeiganga, Dibi, $7^{\circ} 4^{\prime}$ N, $13^{\circ} 47^{\prime}$ E, Polhill et al. 5173 (K); Beka, $14 \mathrm{~km}$ sudOuest de N'Gaoundéré, $7^{\circ} 15^{\prime} \mathrm{N}, 13^{\circ} 30^{\prime} \mathrm{E}$, Van der Zon 1096 (WAG); about $5 \mathrm{~km} \mathrm{~S}$ of Ngaoundéré, $7^{\circ} 17^{\prime} \mathrm{N}, 13^{\circ} 33^{\prime} \mathrm{E}$, W. J. J. O. de Wilde $\mathcal{E}$ de WildeDuyfjes 4618 (BR, P, WAG).

CENTRAL AFRICAN REPUBLIC: Bameiau?, Ouaka, Chevalier 34755 (P); Bambari Region, $8 \mathrm{~km}$ E of Bambari, on the Route d'Etat, $5^{\circ} 41^{\prime} \mathrm{N}$,

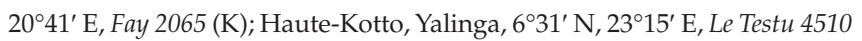
(A, B, BM, BR, K, P); Sangba, 345' N, 1520' E, Peeters Jacques 212 (BR). CHAD: Digue Doba Moundou, Audru 768 (P); Doro, Audru 1096 (P); Banda-Kaga, 9 9 $9^{\prime} \mathrm{N}, 17^{\circ} 51^{\prime} \mathrm{E}$, Chevalier 6688 (BR, P); Laï, 9²4' N, 16 ${ }^{\circ} 18^{\prime} \mathrm{E}$, Koechlin 1868 (P).

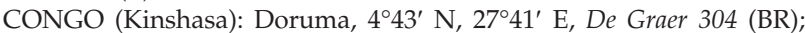
Zangi (ca. Basia), $4^{\circ} 48^{\prime}$ N, $27^{\circ} 39^{\prime}$ E, De Graer 424 (BR); P. N. de la Garamba, Kotshio, $4^{\circ} 13^{\prime}$ N, $2^{\circ} 48^{\prime}$ E, De Saeger 1590 (BR); Orientale, Aru, 252’ N, 3050' E, Ghesquière 6919 (BR, K, P); Ubangi, Ghesquière \& Tihon s. n. (BR); Zongo, Pakker s.n. (BR); P. N. de la Garamba, Km 16, $4^{\circ} 10^{\prime}$ N, $29^{\circ} 30^{\prime}$ E, Troupin 1208 (BR).

GAMBIA: Santang, Dawe 19 (K); Genieri, $13^{\circ} 25^{\prime}$ N, 153' W, Fox 24 (K); Western Division, Kafuta Sawmill, $13^{\circ} 12^{\prime}$ N, $16^{\circ} 28^{\prime}$ W, Kasper \& Descheres 11 (BR).

GHANA: W. of Abene, Kwahu, 6²'소 N, $0^{\circ} 47^{\prime}$ W, Chipp 623 (K); Gold Coast, Dudgeon 101 (K); Brong-Ahafo, Wenchi, Jongkind 2281 (WAG); Brong-Ahafo, along the road from Wenchi to Bamboi, $7^{\circ} 54^{\prime} \mathrm{N}, 2^{\circ} 4^{\prime} \mathrm{W}$, Jongkind \& Nieuwenhuis 1953 (MO, UPS, WAG); Pong-Tamale, Nabago, $9^{\circ} 41^{\prime}$ N, $0^{\circ} 49^{\prime}$ W, Rippstein 284 (P); Mole National Park, $9^{\circ} 14^{\prime}$ N, $1^{\circ} 50^{\prime}$ W, Schmidt, Amponsah \& Welsing 1870 (UPS).

GUINEA: Mamou, Bilima, 10 $23^{\prime} \mathrm{N}, 12^{\circ} 15^{\prime} \mathrm{W}$, Caille in Chevalier 14806 (P); Conakry, $9^{\circ} 33^{\prime} \mathrm{N}, 13^{\circ} 39^{\prime} \mathrm{W}$, Caille s. $n$. (L); Tougué, Kollangui, $11^{\circ} 8^{\prime}$ N, 11 ${ }^{\circ} 49^{\prime}$ W, Chevalier 12872 (P); Cercle de Bokè, $11^{\circ} 5^{\prime}$ N, $14^{\circ} 25^{\prime}$ W, Chillou s. n. (HBG, K); Kouraum, $10^{\circ} 39^{\prime}$ N, $9^{\circ} 53^{\prime}$ W, Mowam s. n. (L); Dar Salam, Dinguiraye, $11^{\circ} 18^{\prime} \mathrm{N}, 10^{\circ} 43^{\prime} \mathrm{W}$, Roberty 10557 (Z).

GUINEA BISSAU: Cacine-Campeane, Alves Pereira 2856 (LISC); Mamou-Dalaba, Chevalier 20243 (P); Arquipélago dos Bijagós, Ilha de Orango, arredores de Eticoga, 11 ${ }^{\circ} 9^{\prime} \mathrm{N}, 16^{\circ} 8^{\prime} \mathrm{W}$, Diniz \& Pinto Basto 2440 (LISC); Contuboel, $12^{\circ} 22^{\prime} \mathrm{N}, 14^{\circ} 34^{\prime} \mathrm{W}$, Gomes \& Correia 2 (LISC); Kalé (Kadé?), Maclaud 52 (P); Kouroussa, Pobéguin 861 (P); Gabu, Tumana, 126' N, 1455' W, Raimundo \& Guerra 863 (C, H, LISC).

IVORY COAST: $5 \mathrm{~km}$ au N de Ferkessédougou, Bamps 2216 (BR); Forest Reserve Kani-Bandama Rouge, 6 6 $53^{\prime}$ N, 532' W, Breteler 13410 (WAG); Mankono-Marabadiassa, J. J. F. E. de Wilde 969 (WAG); Cohoé, Gansé, 3 $\mathrm{km}$ à $1^{\prime} \mathrm{W}$ du bac, $8^{\circ} 37^{\prime} \mathrm{N}, 3^{\circ} 56^{\prime} \mathrm{W}$, Gautier-Béguin $779(\mathrm{G})$; Seguela, $7^{\circ} 57^{\prime} \mathrm{N}$, $6^{\circ} 40^{\prime}$ W, Guy-Alain 89 (BR); Kokondekro, Bavaké (Bareaké), 7³9' N, 5²' W, Mariaux 216 (P); without locality, Aubréville 2686 (P).

MALI: Morsi, Onagadougou-Onahigouya, Chevalier 24700 (P); Cercle de Kita, Kouroukouméné, $14^{\circ} 48^{\prime} \mathrm{N}, 9^{\circ} 44^{\prime} \mathrm{W}, \mathrm{M}$. Dubois 7 (P); $35 \mathrm{~km}$ sud de Kolokani, $13^{\circ} 17^{\prime}$ N, $7^{\circ} 57^{\prime}$ W, Geerling \& Coulibaly 5900 (WAG); without locality, Fougatié 161 (P).

NÍGER: W Koutoumbou, Sabongari, 12²4' N, 33'ㄹ E, Boudet 5196 (P); Sud Guidiguir, 1340' N, 9 950' E, Fabréges 2311 (P); Bosso, Dallol, 12²5' N, $2^{\circ} 50^{\prime}$ E, Virgo $70(\mathrm{~K})$.

NIGERIA: Adamawa province, ca. Jalingo, Chapman 3017 (K, WAG); Oultsha, Chesters 209 (K); Kontagora, Dalziel 16 (K); Ishan, Ugboha, 6 6 45' N, $6^{\circ} 28^{\prime}$ E, Dennett 102 (K); Lagos, 627' N, 323' E, Foster 151 (K); ShakiIseyin, Hambler 122 (K); in Nigerdal, 10-20 km van Jebba, Kamphorst 82 (WAG); Onitsha, $6^{\circ} 10^{\prime} \mathrm{N}, 6^{\circ} 47^{\prime} \mathrm{E}$, Rosever $3 / 29$ (K); Olokemeji reserve, $7^{\circ} 25^{\prime}$ N, $3^{\circ} 32^{\prime}$ E, Ross R. 49 (K).

SENEGAL: Sangalkam, $14^{\circ} 46^{\prime} \mathrm{N}, 17^{\circ} 13^{\prime} \mathrm{W}$, Berhaut $5231 \mathrm{P}$; région de Zinguinchor, Soukouta, Berhaut 6871 (P); Siguiri, Chevalier 286 (P, Z); Casamance, Koulanye, Koraye, Chevalier 2968 (BM, P); Tambacounda, Mamakono, $13^{\circ} 11^{\prime} \mathrm{N}, 12^{\circ} 3^{\prime} \mathrm{W}$, Fotius K790 (P); Sine Saloum, delta du Saloum National Park, $13^{\circ} 40^{\prime} \mathrm{N}, 16^{\circ} 30^{\prime} \mathrm{W}$, Lykke et al. 849 (AAU); $4 \mathrm{~km} \mathrm{~W}$ Koldo, Casamance, 12 $2^{\circ} 53^{\prime}$ N, 14 ${ }^{\circ} 57^{\prime}$ W, Mosnier 2411 (P); Banlankounlon, Trochain 1241 (P); Ziguinchor, Pointe Saint-Georges, 12³8' N, 16³5' W, Van den Berghen 5705 (BR).

SIERRA LEONE: Magbuke (Pendembu), Deighton 4083 (BR, P); Kamakwie road junction with the Makeni-Batkanu to Musaia, $9^{\circ} 30^{\prime} \mathrm{N}$, $12^{\circ} 14^{\prime} \mathrm{W}$, Deighton 4217 (K, P).

SUDAN: Bahr al Ghazäl, Wau-Busseri, $7^{\circ} 41^{\prime}$ N, $28^{\circ} 3^{\prime}$ E, Aylmer GA/27/12 (K); Boro river, in valley $\mathrm{S}$ of Jebel Manda, $8^{\circ} 52^{\prime} \mathrm{N}, 2^{\circ} 11^{\prime} \mathrm{E}$, Hoyle 504 (BM); Yei-Juba, near Ganzi, 4⒉ $9^{\prime}$ N, 31 ${ }^{\circ} 15^{\prime}$ E, Myers 7905 (A, K); Nyin Akok, $7^{\circ} 55^{\prime} \mathrm{N}, 2^{\circ} 1^{\prime} \mathrm{E}$, Turner 91 (K); Loka, Mongaela, $4^{\circ} 16^{\prime} \mathrm{N}, 31^{\circ} 1^{\prime}$ E, Whitehead $3(\mathrm{~K})$.

TOGO: Zwischen Bassar (Bassari) und Lama Kara, Ern 2516 (B); Amoutchou-Tal bei Oga, 7²3' N, 1ํ11' E, Ern 2807 (B); N Bassar, ca. 13 km E von Kabou, bei Santé Hault, Hakki, Leuenberger \& Schiers 472 (B, K).

UGANDA: Adumi, $3^{\circ} 3^{\prime}$ N, 3048' E, Brasnett 308 (K); Nothern, West Nile, Aringa, 3 miles west of Ladonga, $3^{\circ} 26^{\prime} \mathrm{N}, 31^{\circ} 11^{\prime}$ E, Langdale-Brown 2384 (K); Metuli, Madi, 343' N, 3146' E, Thomas 4063 (K).

Discussion-Daniellia oliveri is the sole member of Daniellia subgenus Paradaniellia. It is the most widely distributed species of the genus, found throughout lowland savannah south of the Sahel. Daniellia oliveri may be easily distinguished from 


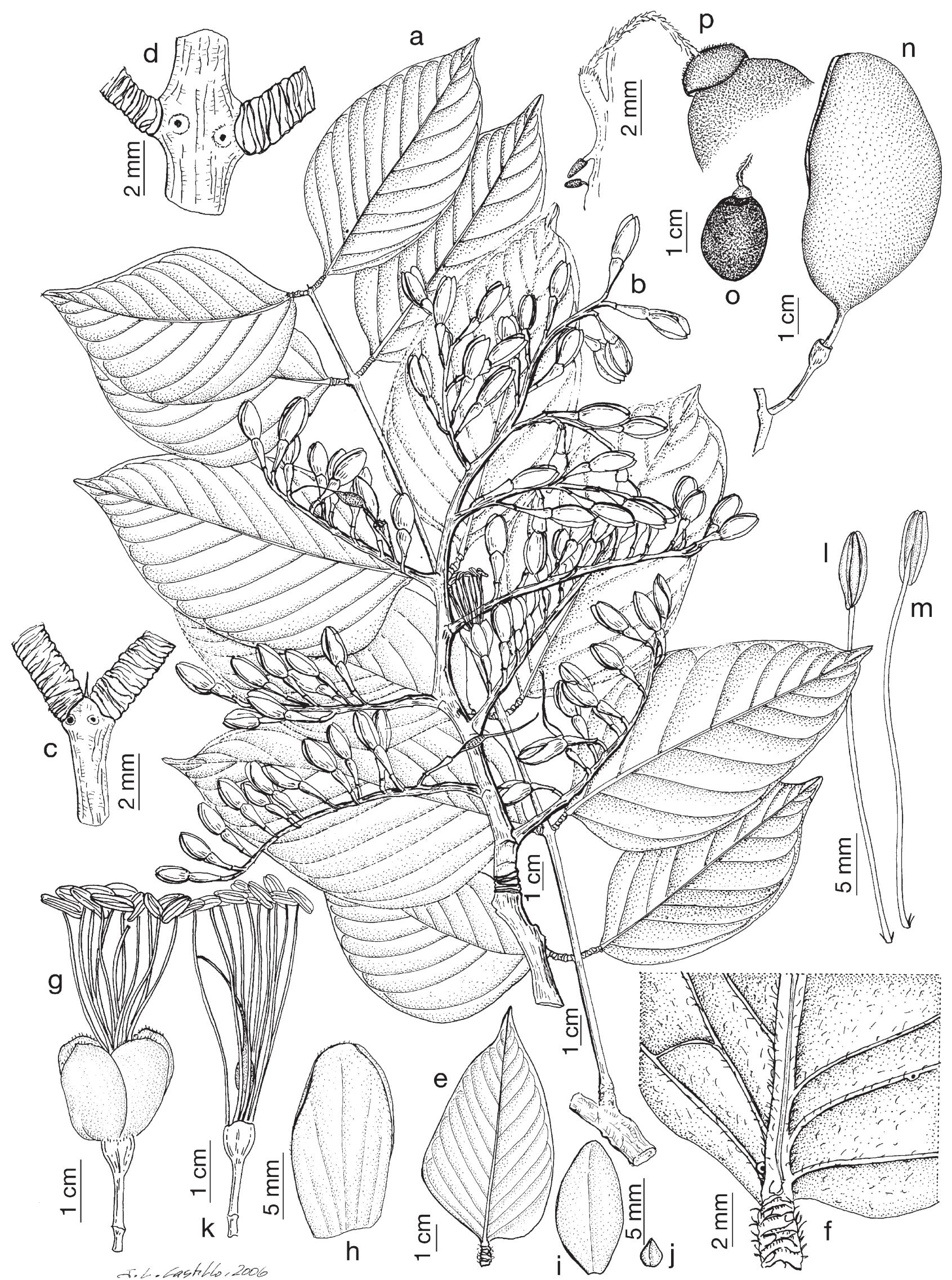

FIg. 16. Daniellia oliveri. a. Twig with leaves. b. Inflorescence. c. Apical pair of leaflets insertion. d. Insertion of basal pair of leaflets. e. Leaflet, abaxial surface. f. Leaflet glands, abaxial surface. g. Flower. h. Sepal seen from inside. i. Lateral petal seen from exterior. j. Abaxial petal seen from exterior. k. Flower without perianth. 1. Stamen front. m. Stamen back. n. Pod. o. Seed. p. Funicle detail. [Based on: a, Jongkind \& Nieuwenhuis 1953 (UPS); b, Hambler 122 (K); c-m, Rosevear 3/29 (K); n-p, Espirito Santo 1514 (M-99080)]. 
other Daniellia species by the relative size of its petals: only one (lateral) petal is large, the other four petals are reduced, as opposed to one medium adaxial petal, two large sized laterals and two reduced abaxials in all other species, and staminal filaments are free and glabrous or nearly so (all other species possess nine united at the base into a tube and pubescent for at least a third of their length; Table 1). Fruiting specimens can also be distinguished by their obovate-elliptic shape (seeds of all other species of Daniellia are oblong to oblong-obovate) and the generally greater seed thickness (5-6 $\mathrm{mm}$ in D. oliveri as compared to $1-5 \mathrm{~mm}$ in other species). Sterile specimens of $D$. oliveri may be confused with those of $D$. alsteeniana but the position of the lamina glands on abaxial leaflet face separate them, as discussed under D. alsteeniana.

When Rolfe (1912, p. 96) described Paradaniellia oliveri he referred to several collections without designating a type: "Tropical Africa. Upper Guinea: Senegambia, Heudelot, 364; Casamance, at Koulaye Kouraye, Chevalier, 2969; Northern Nigeria: Nupe, Barter, 978; Kontagora, Dudgeon, 62; Dalziel, 16; Southern Nigeria: Lagos, Foster, 151; Ishan County, Dennet, 102; without precise locality, Unwin, 23. Chari oriental, Dar Banda, Chevalier, 6638". Léonard (1950, p. 120) stated that the type material of this species was "Sénégambie: Heudelot 364 (typus, Herb. Kew, double Herb. Mus. Paris)" and lectotypified Heudelot 364 (K; isolectotype: P).

\section{Excluded NAmes}

Afrodaniellia Stapf ex A. Chev., Bois du Gabon: 164. 1917. nom. nud.

Daniella auct. orthographical error.

Paradaniellia Rolfe, Bull. Misc. Inform. Kew, Addit. Ser. 9: 270. 1911, nom. nud.

Paradaniellia oliveri, Bull. Misc. Inform. Kew, Addit. Ser. 9: 270. 1911, nom. nud.

Daniellia lynessii Staner ex J. Léonard, Inst. Natl. Étude Agron. Congo Belgue, Sér. Sci. 45: 112 (1950), nom. nud., pro syn.

Cyanothyrsus ogea Harms, Engler \& Prantl, Nat. Pflanzenfam., Nachtr. II-IV, 1: 197. 1897, nom. nud.

Cyanothyrsus pynaertii De Wild., Bull. Jard. Bot. État Bruxelles 7: 261 (1920), nom. nud., pro syn.

Cyanothyrsus mortehanii De Wild., Bull. Jard. Bot. État Bruxelles 7: 260. 1920., nom. nud., pro syn.

Cyanothyrsus soyauxii Harms, Engler \& Prantl, Nat. Pflanzenfam., Nachtr. II-IV, 1: 197. 1897, nom. nud.

Cyanothyrsus klainei Pierre ex De Wild., Bull. Jard. Bot. État Bruxelles 7: 259. 1920, in sched.

AcKNowLEDGMENTs. The authors wish to thank the staff of the cited herbaria for their support on our visit and/or loan of material. We also are indebted to J. J. Wieringa, G. P. Lewis and two anonymous reviewers for their advice and suggestions on the manuscript, J. L. Castillo for his comments on the flowers of D. thurifera, and M. Laínz for the Latin diagnosis. This work was financed by the Flora of Equatorial Guinea project (CGL 2006-01223). Manuel de la Estrella was funded by a Universidad Complutense de Madrid predoctoral grant and visited BR and P herbaria under FPVI European-funded Integrated Infrastructure Initiative grant SYNTHESYS, BE-TAF 2142 and FR-TAF 2745 projects, respectively.

\section{Literature Cited}

Aubréville, A. 1950. Flore forestière Soudano-Guinéenne. Paris: Sociéte d'Éditions Géographiques, Maritimes et Coloniales.
Aubréville, A. 1959. La flore forestière de la Côte d'Ivoire vol. 1. Ed. 2. NogentSur-Marne: Centre Technique Forestier Tropical.

Aubréville, A. 1970. Flore du Cameroun 9. Légumineuses - Caesalpinoidées. Paris: Muséum National d'Histoire Naturelle.

Baker, E. G. 1930. The Leguminosae of tropical Africa. Ostend: Unitas Press.

Banks, H. and B. B. Klitgaard. 2000. Palynological contribution to the systematics of detarioid legumes (Leguminosae: Caesalpinioideae). Pp. 79-106 in Advances in legume systematics vol. 9, ed. P. S. Herendeen and A. Bruneau. Kew: Royal Botanic Gardens.

Bennett, J. J. 1854. Description of the bungo, or frankincense tree of Sierra Leone. Pharmaceutical Journal and Transactions 14: 252-253.

Berhaut, J. 1967. Flore du Sénégal. Dakar: Éditions Clairafrique.

Brenan, J. P. M. 1967. Flora of tropical east Africa, Leguminosae, subfamily Caesalpinioideae. London: The Crown agents for overseas governments and administrations.

Breteler, F. J. 2005. Novitates Gabonenses 55. Manuscript names and drawings of the French botanist Louis Pierre (1833-1905): a discussion about their validity with some examples of nomenclatural consequences for the Gabonese flora in particular. Adansonia sér. 3, 27: 325-335.

Bruneau, A., F. Forest, P. S. Herendeen, B. B. Klitgaard, and G. P. Lewis. 2001. Phylogenetic relationships in the Caesalpinioideae (Leguminosae) as inferred from chloroplast trnL intron sequences. Systematic Botany 26: 487-514.

Burkill, H. M. 1995. The useful plants of west tropical Africa, vol. 3, Families J-L. Kew: Royal Botanic Gardens.

Chevalier, A. 1916. La forêt et les bois du Gabon. Paris: Challamel.

Chevalier, A. 1920. Exploration botanique de L'Afrique occidentale Française Tome I. Paris: Paul Lechevallier.

Cowan, R. S. and R. M. Polhill. 1981. Detarieae. Pp. 117-134 in Advances in legume systematics vol. 1, ed. R. M. Polhill and P. H. Raven. Kew: Royal Botanic Gardens.

Duvigneaud, P. 1949. Voyage botanique au Congo Belge a travers le BasCongo, le Kwango, le Kasaï et le Katanga. Bulletin de la Société Royale de Botanique de Belgique 81: 15-33.

Estrella, M., C. Aedo, and M. Velayos. 2007. Daniellia pilosa (J. Léonard) Estrella, comb. \& stat. nov. (Leguminosae). Annales Botanici Fennici 44: $149-150$

Estrella, M., C. Aedo, and M. Velayos. 2009. A morphometric analysis of Daniellia (Leguminosae-Caesalpinioideae). Botanical Journal of the Linnean Society 159: 268-279.

Fougère-Danezan, M., S. Maumont, and A. Bruneau. 2007. Relationships among resin-producing Detarieae s. 1. (Leguminoae) as inferred by molecular data. Systematic Botany 32: 748-761.

Harms, H. 1897. Cyanothyrsus. P. 197 in Die natürlichen Pflanzenfamilien nebst ihren Gattungen und wichtigeren Arten. Nachträge zum II-IV Teil, ed. A. Engler and K. Prantl. Leipzig: Verlag von Wilhelm Engelmann.

Harms, H. 1899. Leguminosae Africanae 2. Botanische Jahrbücher für Systematik, Pflanzengeschichte und Pflanzengeographie 26: 253-324.

Harms, H. 1908. Daniellia. Pp. 153 in Die natürlichen Pflanzenfamilien nebst ihren Gattungen und wichtigeren Arten. Nachträge II und III sum II-IV Teil, über die Jahre 1897 bis 1904, ed. A. Engler and K. Prantler. Leipzig: Verlag von Wilhelm Engelmann.

Hawthorne, W. and C. C. H. Jongkind. 2006. Woody plants of western African forests. A guide to the forest trees, shrubs and lianes from Senegal to Ghana. Kew: Royal Botanic Gardens.

Herendeen, P. S., A. Bruneau, and G. P. Lewis. 2003. Phylogenetic relationships in the caesalpinioid legumes: a preliminary analysis based on morphological and molecular data. Pp. 37-62 in Advances in legume systematics vol. 10, eds. B. B. Klitgaard and A. Bruneau. Kew: Royal Botanic Gardens.

Hutchinson, J. and J. M. Dalziel. 1928a. Tropical African plants 4. Bulletin of Miscellaneous Information. Kew 9: 380-382.

Hutchinson, J. and J. M. Dalziel. 1928b. Flora of west tropical. Africa 1(2). London: The Crown agents for the Colonies.

Keay, R. W. J. 1954. Revision of the "Flora of west tropical Africa" 4. Kew Bulletin 4: 487-492.

Keay, R. W. J. 1958. Flora of west tropical Africa, vol. 1(2). Ed. 2. London: The Crown agents for overseas governments and administrations.

Koning, J. de 1983. La forêt du Banco, 2. La flore. Section de Taxonomie et de Géographie botaniques, Université Agronomique de Wageningen 83-1: $1-156$.

Léonard, J. 1950. Étude botanique des copaliers du Congo Belge. Publications de l'Institut National pour l'Étude Agronnomique du Congo Belge. Série Scientifique 45: 1-158.

Léonard, J. 1952. Cynometreae et Amherstieae. Pp. 279-495 in Flore du Congo Belge et du Ruanda-Urundi vol. 3, ed. W. Robyns. Bruxelles: 
Publications de l'Institut National pour l'Étude Afronomique du Congo Belge (I. N. É. A. C.)

Mackinder, B. A. 2005. Detarieae sensu lato. Pp. 69-109 in Legumes of the world, ed. G. Lewis, B. Schrire, B. Mackinder, and M. Lock. Kew: Royal Botanic Gardens.

Oliver, D. 1871. Flora of tropical Africa vol. 2. London: Published under the Authority of the First Commissioner of Her Majestry's Works.

Pellegrin, F. 1949. Les Légumineuses du Gabon. Paris: Mémoires de l'Institut d'Études Centrafricaines.

Rico, M. L. and S. Bachman. 2006. A taxonomic revision of Acaciella (Leguminosae, Mimosoideae). Anales del Jardín Botánico de Madrid 63: 189-244.

Rolfe, R. 1912. Paradaniellia oliveri. Kew Bulletin of Miscellaneous Information. 1912: 96.
Theobald, W. L., J. L. Krahulik, and R. C. Rollins. 1979. Trichome description and classification. Pp. 40-53 in Anatomy of the dicotyledons, vol. 1, ed. C. R. Metcalfe and L. Chalk. Ed. 2. Oxford: Clarendon Press.

Timberlake, J. R., G. V. Pope, R. M. Polhill, and E. S. Martins. 2007. Flora Zambesiaca vol. 3(2). Kew: Royal Botanic Gardens.

Ulbrich, E. 1932. "Pende-Schraubenflieger", ein neuer Typus von Flugfrüchten bei Gehölzen des tropischen Afrika. Notizblatt des Botanischen Gartens und Museums zu Berlin-Dahlem 11: 503-509.

Wieringa, J. J. 1999. Monopetalanthus exit. A systematic study of Aphanocalyx, Bikinia, Icuria, Michelsonia and Tetraberlinia (Leguminosae, Caesalpinioideae). Wageningen Agricultural University Papers 99-4: $1-320$.

Wildeman, E., de 1920. Observations sur des Légumineuses de la flore Africaine. Bulletin du Jardin Botanique de l'État 7: 219-270. 